\title{
Phylogenetic analysis of the Neotropical Albitarsis Complex based on mitogenome data
}

Brian P. Bourke ${ }^{1,2,3^{*}}$, Silvia A. Justi ${ }^{1,2,3}$, Laura Caicedo-Quiroga ${ }^{1,2,3}$, David B. Pecor ${ }^{1,2,3}$, Richard C. Wilkerson ${ }^{1,2,3}$ and Yvonne-Marie Linton 1,2,3

\begin{abstract}
Background: Some of the most important malaria vectors in South America belong to the Albitarsis Complex (Culicidae; Anophelinae; Anopheles). Understanding the origin, nature, and geographical distribution of species diversity in this important complex has important implications for vector incrimination, control, and management, and for modelling future responses to climate change, deforestation, and human population expansion. This study attempts to further explore species diversity and evolutionary history in the Albitarsis Complex by undertaking a characterization and phylogenetic analysis of the mitogenome of all 10 putative taxa in the Albitarsis Complex.

Methods: Mitogenome assembly and annotation allowed for feature comparison among Albitarsis Complex and Anopheles species. Selection analysis was conducted across all 13 protein-coding genes. Maximum likelihood and Bayesian inference methods were used to construct gene and species trees, respectively. Bayesian methods were also used to jointly estimate species delimitation and species trees.

Results: Gene composition and order were conserved across species within the complex. Unique signatures of positive selection were detected in two species - Anopheles janconnae and An. albitarsis G-which may have played a role in the recent and rapid diversification of the complex. The $\mathrm{CO} / \mathrm{gene}$ phylogeny does not fully recover the mitogenome phylogeny, and a multispecies coalescent-based phylogeny shows that considerable uncertainty exists through much of the mitogenome species tree. The origin of divergence in the complex dates to the Pliocene/Pleistocene boundary, and divergence within the distinct northern South American clade is estimated at approximately 1 million years ago. Neither the phylogenetic trees nor the delimitation approach rejected the 10-species hypothesis, although the analyses could not exclude the possibility that four putative species with scant a priori support (An. albitarsis G, An. albitarsis $\mathrm{H}$, An. albitarsis I, and An. albitarsis J), represent population-level, rather than species-level, splits.
\end{abstract}

Conclusion: The lack of resolution in much of the species tree and the limitations of the delimitation analysis warrant future studies on the complex using genome-wide data and the inclusion of additional specimens, particularly from two putative species, An. albitarsis I and An. albitarsis J.

Keywords: Malaria, Mitogenome, Mosquito, Phylogenetics, Plasmodium, Vector

*Correspondence: bourkeb@si.edu

1 Walter Reed Biosystematics Unit, Smithsonian Institution Museum Support Center, MRC-534, 4210 Silver Hill Rd., Suitland, MD 20746, USA

Full list of author information is available at the end of the article original author(s) and the source, provide a link to the Creative Commons licence, and indicate if changes were made. The images or other third party material in this article are included in the article's Creative Commons licence, unless indicated otherwise in a credit line to the material. If material is not included in the article's Creative Commons licence and your intended use is not permitted by statutory regulation or exceeds the permitted use, you will need to obtain permission directly from the copyright holder. To view a copy of this licence, visit http://creativecommons.org/licenses/by/4.0/. The Creative Commons Public Domain Dedication waiver (http://creativeco mmons.org/publicdomain/zero/1.0/) applies to the data made available in this article, unless otherwise stated in a credit line to the data. 


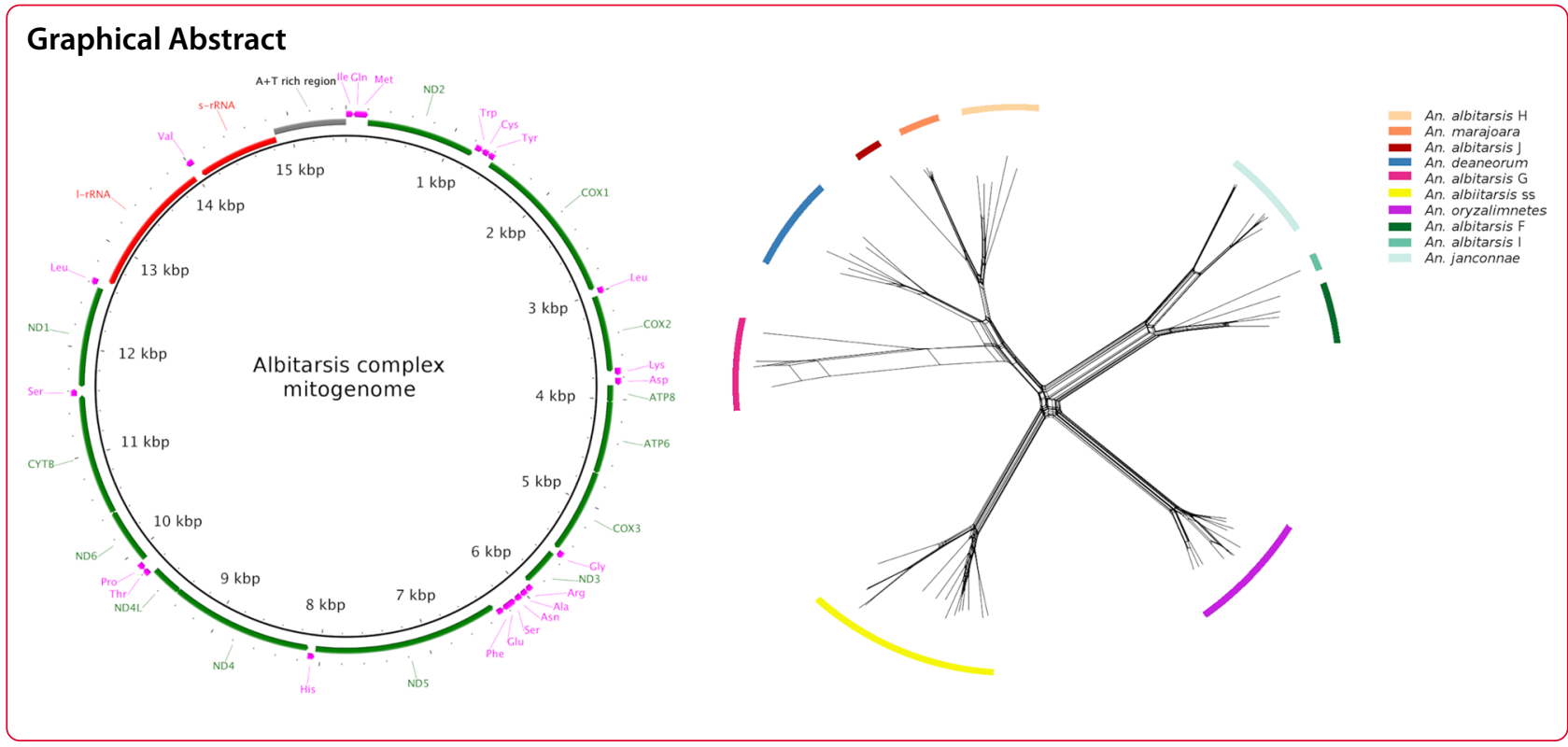

\section{Background}

Vector-borne diseases account for almost one fifth of the global burden of infectious diseases [1]. The most important of these is malaria, which is responsible for more than 400,000 deaths annually [2]. This disease is caused by Plasmodium parasites transmitted to humans through the bites of Anopheles mosquitoes. Five species of Plasmodium cause malaria in humans [3, 4], but two-Plasmodium falciparum and Plasmodium vivaxare considered the greatest threat. The former is the predominant species in Africa, where almost 95\% of global malaria cases and deaths occur, while the latter predominates in the Americas, accounting for $75 \%$ of the approximately 1 million cases reported annually [2].

Within the Americas, Plasmodium is transmitted by a diverse array of mosquito vectors [5], the most important of which is Anopheles darlingi, found through much of South and Central America [6]. Many of the other dominant vector species [5] are morphologically indistinguishable from benign close relatives, and the existence of such cryptic groups or complexes obscures ecological and life history differences that may be of public health importance and complicates incrimination and targeted control strategies. Among the most important of these are species belonging to the Albitarsis Complex [5]. This complex currently comprises 10 known and putative species, variously distributed across Argentina, Bolivia, Brazil, Colombia, French Guiana, Paraguay, Trinidad, and Venezuela [7-11]. At least three are highly competent vectors. The importance of An. marajoara in Plasmodium transmission in the Brazilian Amazon is comparable to that of An. darlingi in established forest settlements
[12], while it has been found to be the most important malaria vector at emerging frontier settlements [13]. It is also found as a potentially important vector at artisanal gold mines in the forests of French Guiana [14]. In laboratory-based transmission studies, Plasmodium infection rates of $A n$. deaneorum were comparable to the primary South American malaria vector, An. darlingi $[15,16]$. In the field, An. deaneorum are found naturally infected with $P$. vivax and/or P. falciparum, and natural infection rates combined with high local abundance in the state of Acre, Brazil, support its importance in local malaria transmission [17]. Anopheles janconnae [18] is the primary malaria vector in the savannah surrounding Boa Vista in the Brazilian state of Roraima. The public health importance of the remaining members of the Albitarsis Complex is poorly understood, but based on overlap of distribution of sustained malaria transmission, the spatial evolutionary and ecological vicariance analysis (SEEVA) of Foley et al. [19] suggested that An. albitarsis G, H, and I may also play significant roles in malaria transmission. Difficulty with species identification can lead to problems with vector incrimination, and surveys of Plasmodium vectors frequently identify these specimens only as $A n$. albitarsis sensu lato [20-25]. In addition, many of the species in the complex, including An. marajoara and $A n$. deaneorum, are predicted to expand their distributions due to the effects of climate change and are therefore likely to be of increasing public health importance in the future [26].

A variety of morphological [27-30] and molecular [7, 9, 31-39] approaches have been employed to discriminate species and explore species relationships within the 
Albitarsis Complex. Phylogenetic studies have played a particularly important role in describing this species complex's diversity, but they have recovered conflicting topologies and uncertainty concerning species relationships [7, 35-38]. The work of Ruiz-Lopez et al. [7] and Motoki et al. [11] supported a basal split that separates northern and southern continental species at the mitochondrial cytochrome c oxidase I (COI) gene. However, this branching order has not been recovered in other studies using other regions of the COI gene [36] or the mitogenome [37, 38]. Hypothesized sister relationships, such as those with An. albitarsis G and An. oryzalimnetes, also vary both within and between these studies.

The mitogenome has rapidly become a popular marker for phylogenetic analyses in recent years. Given its maternal inheritance and limited recombination [40], different regions in the mitogenome are expected to have the same evolutionary history. Variation among mitochondrial gene trees is therefore generally attributed to systematic error rather than biological process [41]. The conserved gene composition of the mitogenome makes establishing orthology simple, and the mitogenome's high mutation rates and considerable size (reducing stochastic error) make it attractive for establishing phylogenies of closely related species, such as the putative species within the Albitarsis Complex. We then describe mitogenomic relationships among these species using traditional phylogenetic and multispecies coalescent methods and discuss the significance of our findings in the context of Albitarsis Complex history and phylogeography. Our findings provide important insights for future studies of speciation in the complex.

\section{Methods}

\section{Collection}

Specimens sequenced for this molecular study were previously morphologically identified in Ruiz et al. [7] and Motoki et al. [11] as belonging to the Albitarsis Complex using the available keys [30, 42]. These specimens have been stored as vouchers or had their DNA stored in archive collections of the Walter Reed Biosystematics Unit (WRBU), Smithsonian Institution-National Museum of Natural History, Museum Support Center (MSC), Suitland, Maryland, USA, or in the frozen tissue collection at the Natural History Museum, London, UK.

\section{DNA extraction and sequencing}

DNA was extracted according to the method reported by Gilbert et al. [43]. Each specimen was placed in a $1.5 \mathrm{ml}$ tube and fully immersed in a digestion buffer, which consisted of $3 \mathrm{mM} \mathrm{CaCl}, 2 \%$ sodium dodecyl sulphate (SDS), $40 \mathrm{mM}$ dithiothreitol (DTT), $250 \mu \mathrm{g} / \mathrm{ml}$ proteinase $\mathrm{K}, 100 \mathrm{mM}$ Tris buffer $\mathrm{pH} 8$, and $100 \mathrm{mM} \mathrm{NaCl}$. This was incubated for at least $18 \mathrm{~h}$ on a slow shaker at $55^{\circ} \mathrm{C}$. DNA was then precipitated using a solution containing $0.6 \times$ digestion buffer volume of isopropanol, $0.1 \times$ digestion buffer volume of $3 \mathrm{M}$ sodium acetate $\mathrm{pH} 5.2$, and $0.01 \times$ digestion buffer volume of Ambion GlycoBlue. The detailed protocol was published in Justi et al. (2021) and is available on the WRBU website at https://wrbu.si.edu/ docs/sops/MolLabSOP1.pdf.

DNA was quantified for all samples using the Qubit High Sensitivity Assay Kit for fluorometric quantification (Thermo Fisher Scientific, Waltham, MA, USA). In cases where the DNA concentration was too low to quantify, the DNA solution was concentrated by evaporation using a Savant SpeedVac Plus centrifuge vacuum concentrator and re-quantified.

Illumina library preparation was performed using KAPA HyperPlus Kits (Roche, Basel, Switzerland). Highly fragmented DNA identified by an Agilent 4200 TapeStation automated electrophoresis system (Agilent Technologies, Santa Clara, CA, USA) required DNA end repair and A-tailing steps following the manufacturer's protocol. Adapter ligation and polymerase chain reaction (PCR) amplification was in accordance with the manufacturer's recommendations. Subsequent quality control and fragment distribution were again assessed with the 4200 TapeStation (Agilent Technologies), and AMPure XP bead (Beckman Coulter, Brea, CA, USA) clean-up was performed to remove adapter dimers and other impurities, when necessary. The detailed protocol, based on the KAPA HyperPlus technical datasheet, is available on the WRBU website at https://wrbu.si.edu/docs/sops/ MolLabSOP2.pdf. Sequencing was performed using the NovaSeq Illumina platform $($ PE $2 \times 150)$ at the Walter Reed Army Institute of Research (WRAIR), Silver Spring, MD, USA. Read quality was checked using fastqc [44].

\section{Mitogenome assembly and annotation}

Mitogenomes were assembled de novo from wholegenome data using NOVOPlasty [45]. Assembled mitogenomes were then annotated for protein-coding genes (PCGs) and ribosomal RNAs (rRNAs) in Geneious Prime 2020.1.1 (https://www.geneious.com) using the An. albitarsis mitochondrial reference genome (NC_020662), and adjusted, where appropriate, using the recommendations of Cameron [46]. The transfer RNAs (tRNAs) were inspected by comparison with the annotation approach described by Jühling et al. [47] and implemented in MITOS [48]. Annotations in the Albitarsis Complex were visualized using the BLAST Ring Image Generator [49]. Each specimen was identified according to the 10-member Albitarsis Complex detailed in Motoki et al. [11], using COI barcode data described therein. Sequencing yielded 35 mitogenomes, which were combined with 
an additional 25 mitogenomes from GenBank for subsequent mitogenomic analyses (Additional file 1: Table S1).

\section{Alignments}

All gene sequences were aligned by nucleotide position using the MUSCLE [Multiple Sequence Comparison by Log-Expectation] algorithm [48] implemented in SeaView [50]. The PCGs were also aligned by amino acid using TranslatorX [51]. AT composition and site variation was calculated using MEGA [52]. The extent of substitution saturation at the third codon position was tested using the index of substitution saturation (ISS) test of Xia et al. [53] and implemented in DAMBE [54].

\section{Selection analyses}

Radical physicochemical amino acid changes at the 13 PCGs of the mitogenome were identified using TreeSAAP [55]. This approach compares the distribution of physicochemical changes inferred from a phylogenetic tree with the expected distribution of random changes expected under selective neutrality. The magnitude of the changes was assigned to eight classes, representing conservative (tending towards class 1 ) and radical (tending towards class 8) changes in amino acid characteristics. Only the most radical changes (classes 6 to 8; critical $Z$-score values for $P=0.001$ of 3.09 and -3.09 , indicating positive and negative selection, respectively) were of interest. To reduce the potential for false-positive results, physicochemical properties that had an accuracy of detection of selection lower than $85 \%$ (11 of 31) were excluded from the analysis, as recommended by McClellan and Ellison [56]. Each gene was analyzed separately using a maximum likelihood tree of the PCG alignment as the input tree. TreeSAAP results were summarized and viewed in IMPACT_S [57]. Under the evolutionary pathway (Evpthwy) tab, results from the sliding window analyses were graphed, highlighting the positions across the PCGs of each significant radical property. Under the substitutions (Substs) tab, the "properties by site" tables showed the specific codon, amino acid, and branch position of each significant radical property.

\section{Phylogenetic analyses}

We employed two methods to confirm tree-like structure in the mitogenomic data. Firstly, we used the four-cluster likelihood mapping (FCLM) method [58] implemented in IQ-TREE [59]. The method calculates the maximum likelihood for the three fully resolved tree topologies possible from all unique sequence quartets in the data (using option -lmap ALL). The three corners of an equilateral triangle represent the three fully resolved topologies, and a point within this triangle represents the maximum likelihood value of each topology. Datasets with strong phylogenetic content have most points mapped to fully resolved regions of the triangle (corners), while those with a low phylogenetic signal have a significant proportion of points mapped to unresolved regions of the triangle (center). Secondly, we used the NeighborNet algorithm implemented in SplitsTree [60] to construct a phylogenetic network and assess whether the data nature was tree-like, with a bifurcating phylogeny, or networklike, with reticulation and conflicting phylogenetic signals.

Maximum likelihood phylogenetic analyses were performed on PCG and PCG + rRNA alignments. Maximum likelihood gene trees were inferred using IQ-TREE [59] and optimal models (-mset mrbayes) found using ModelFinder [61]. Selection of an appropriate outgroup followed the recommendations of Grant [62], by including the closest known sister taxa and successively expanding the outgroup sample until ingroup topology was shown to be stable in at least two iterations. Outgroup sampling included specimens from the subgenera Nyssorhynchus (An. braziliensis, NC037791; An. darlingi, NC014275; An. evansae, MF381711; An. nuneztovari, MF381680; An. strodei, NC037808), Anopheles (An. minor, MF381684), Kerteszia (An. cruzii, NC024740; An. homunculus; NC030248), and Stethomyia (An. kompi, NC037827; An. nimbus, NC037811). The TIGER [Tree Independent Generation of Evolutionary Rates] method of Cummins and McInerney [63] was used to identify the most rapidly evolving sites in the PCG alignment, which may be a source of noise with little phylogenetic signal. Sites were placed into 10 bins, and those in the fastest bin (bin 10) were removed. The resulting "slow site" alignment was then input for phylogenetic analysis, as above.

\section{Species tree and species delimitation}

StarBEAST2 [64] was used to construct a time-calibrated species tree using the multispecies coalescent method. Divergence times among species in the complex were estimated using the insect mitochondrial substitution rate of 0.0115 mutations/nucleotide/million years described by Brower [65]. All PCGs were considered linked across tree, site, and clock models. A strict and an uncorrelated log-normal relaxed clock model was run, using a Yule tree prior, analytical population size integration, and an uninformative prior $(1 / x)$ for population size. The site model was set to the optimal model for ingroup sequences: $\mathrm{HKY}+\mathrm{I}+\mathrm{G}$. The analysis was run for $1 \times 10^{8}$ steps with sampling every $5 \times 10^{4}$ steps. Adequate mixing was achieved by ensuring that the effective sample size (ESS) of all parameters was greater than 200. Duplicate runs were performed to check for consistency.

The unguided Bayesian species delimitation method (A11 model; [66]), implemented in Bayesian 
Phylogenetics and Phylogeography (BPP; [67]), was used to jointly estimate the species tree and the species delimitation using the multispecies coalescent model and reversible-jump Markov chain Monte Carlo (rjMCMC) analyses in a Bayesian framework. Population size parameter $(\theta)$ was assigned an inverse-gamma prior run for different values: IG(3, 0.005), IG(3, 0.01), and $\operatorname{IG}(3,0.02)$, i.e., $\operatorname{IG}(\alpha, \beta)$, giving a mean of $m=\beta /(\alpha$ -1 ), or mean species nucleotide diversity of $0.25,0.5$ and $1.0 \%$. We considered these to be a realistic range of estimates for diversity in the Albitarsis Complex, where mean nucleotide diversity among species was estimated at $0.87 \%$, based on $C O I$ barcodes sequenced in Motoki et al. [11]. Divergence times at the root of the species tree $(\tau)$ were assigned inverse-gamma priors IG(3, 0.04), IG(3, $0.05)$, and $\mathrm{IG}(3,0.06)$, giving means for $\mathrm{\tau}$ of $0.02,0.025$, and 0.03 , i.e., $2-3 \%$ sequence divergence between the root of the species tree and the present time. This estimate is comparable to $p$-distance derived from a midpoint-rooted neighbor-joining tree $(2.1 \%)$. Population size $(\theta)$ and divergence time $(\tau)$ priors were denoted as low $\left(\theta_{\text {low }}, \tau_{\text {low }}\right)$, medium $\left(\theta_{\text {med }}, \tau_{\text {med }}\right)$, and high $\left(\theta_{\text {high }}, \tau_{\text {high }}\right)$. Duplicate runs were performed using both rjMCMC algorithm 0 (with $\in=2$ ) and 1 (with $\alpha=2$ and $m=1$ ) to check for consistency. The importance of the starting tree on output was also tested using the maximum likelihood topology tree and a random topology tree. For each run, 100,000 samples were collected by sampling every five iterations after a burn-in of 20,000 iterations.

\section{Results}

The geographical distribution of specimens analyzed in this study can be seen in Fig. 1. The complete mitogenomes from the Albitarsis Complex comprised 13 PCGs, two rRNA genes, 22 tRNA genes, and an AT-rich region (Fig. 2). Mitogenome lengths varied from 15,206 base pairs (bp) in An. janconnae 51912405, to $15,525 \mathrm{bp}$ in An. deaneorum MF381590 (an exception was An. janconnae 51912453, which was 14,047 bp in length and suffered from low coverage and poor assembly around the AT-rich region). Gene composition and order in the mitogenomes were consistent across all species (Fig. 2; Additional file 2: Table S2).

\section{Selection}

TreeSAAP sliding window analysis indicated six physicochemical properties undergoing positive selection in eight of the 13 PCGs (Fig. 3). Positive selection in the equilibrium constant (ionization of $\mathrm{COOH}$ ) property was found to be the most widespread, occurring in five of the PCGs. Positive selection in alpha-helical tendencies was detected in ATP6 and ND3, while positive selection for the remaining four physicochemical properties occurred in a short 94-bp section of the ND4l gene. When mapping physicochemical property changes to branch position, positive selection was detected at four internal branches (considered true candidate variants of positive selection). One of these, a change from serine to leucine at the ND2 gene and increasing chromatographic index, was unique to $A n$. janconnae. Another, a change from isoleucine to asparagine at the ND5 gene and increasing polarity, was unique to An. albitarsis G. The remaining two changes, serine to phenylalanine at the ND1 gene (increasing chromatographic index and solvent-accessible reduction ratio) and glutamate to lysine at the ND3 gene (increasing isoelectric point), were associated with intraspecific branches in the An. albitarsis and An. oryzalimnetes clades, respectively.

Prior to undertaking phylogenetic analyses, we assessed alignments for variability and checked codon position 3 among PCGs for substitution saturation (Additional file 3: Table S3; Additional file 4: Table S4). The PCG alignment had considerably more information content (13 genes; parsimony-informative sites $=10-195)$ than the rRNA and tRNA alignments. The tRNA alignment was least informative (22 genes; parsimony-informative sites $=0-3$ ), and was excluded from subsequent phylogenetic analyses. No signal of substitution saturation at codon position 3 was detected in the PCG alignment.

\section{Network- versus tree-likeness}

The construction of a NeighborNet graph using both PCG and PCG + rRNA alignments showed a clear tree-like structure to the data (Fig. 4; Additional file 5: Figure S1). Similarly, FcLM analysis for the two sets of alignments found strong tree-likeness in the data, with more that 96\% of all topologies found in tree-like regions of the map (Additional file 6: Figure S2; Additional file 7: Figure S3).

\section{Mitogenome gene tree}

Iterative expansion of outgroup samples did not substantially alter ingroup topology and support. The first iteration of the outgroup (An. braziliensis, An. darlingi, and $A n$. strodei) was therefore the one used in subsequent phylogenetic analyses. Maximum likelihood trees constructed from both PCG and PCG + rRNA alignments yielded a consistent tree topology (Fig. 5 and Additional file 8: Figure S4, respectively). The 10 species of the Albitarsis Complex mitogenomes were resolved. Eight of these 10 species formed strongly supported ( $\geq 97 \%$ bootstrap support, BS) monophyletic clades. The remaining two species, An. albitarsis I and An. albitarsis J, were each represented by a single mitogenome, and so the monophyly of these two species could not be properly tested. The most basal split in the tree formed a four-way polytomy. The clades formed from this polytomy comprised An. albitarsis (100\% BS), An. oryzalimnetes (100\% 


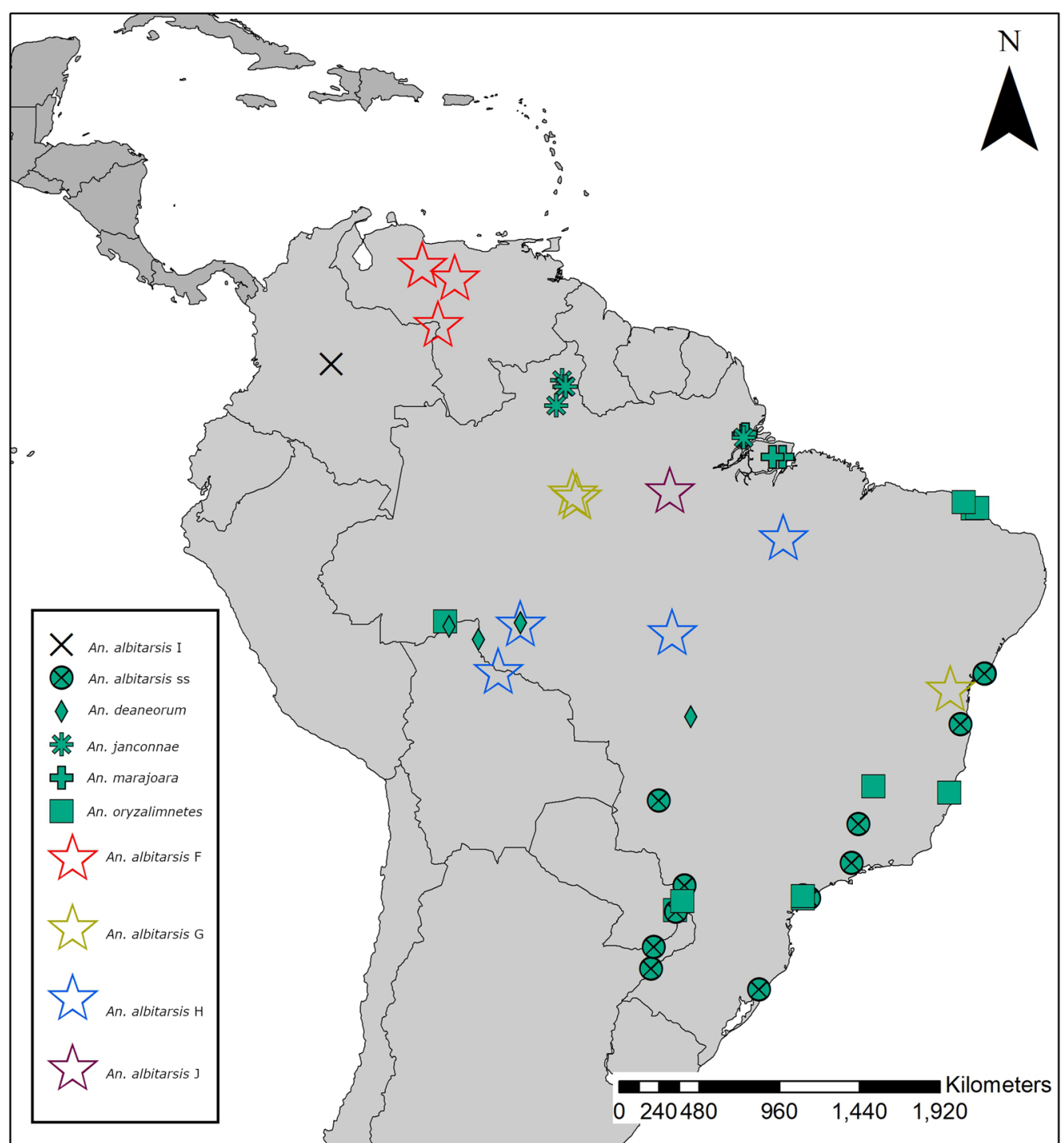

Fig. 1 Collection localities for the Albitarsis Complex specimens. For illustrative purposes, locations have been jittered to reduce overplotting

BS), An. albitarsis $\mathrm{F}+$ An. albitarsis $\mathrm{I}+$ An. janconnae (100\% BS), and An. albitarsis $\mathrm{G}+A n$. albitarsis $\mathrm{H}+A n$. albitarsis $\mathrm{J}+$ An. deaneorum + An. marajoara (100\% BS). PCG and PCG + rRNA alignments with exclusion of the fastest-evolving sites yielded the same topology as the whole datasets, with comparable levels of support across the trees (Additional file 9: Figure S5).

\section{$\mathrm{COI}$ and $\mathrm{COI}$ barcode gene trees}

Maximum likelihood trees of both the $C O I$ gene and the $C O I$ barcode region yielded considerably different topologies from that of the mitogenome. Discordance between $C O I$ trees and the mitogenome tree are represented by red nodes, where splits and polytomies differ, and red branches, where species clades are not monophyletic (Fig. 6a, b). In the COI tree (Fig. 6b), $A n$. albitarsis and An. oryzalimnetes formed a new sister relationship in a separate clade, while the An. albitarsis $\mathrm{G}+$ An. albitarsis $\mathrm{H}+$ An. albitarsis $\mathrm{J}+$ An. deaneorum $+A n$. marajoara clade found in the mitogenome phylogeny fragmented and formed part of a six-way basal polytomy. The An. albitarsis $\mathrm{H}+$ An. albitarsis $\mathrm{J}+A n$. marajoara clade was retained, while $A n$. albitarsis $\mathrm{G}$ was found to be no longer monophyletic. The COI barcode tree (Fig. 6a) displayed greater discordance with the mitogenome phylogeny than the $C O I$ tree. The An. albitarsis F $+A n$. albitarsis $\mathrm{I}+A n$. janconnae clade, which was found in the basal four-way 


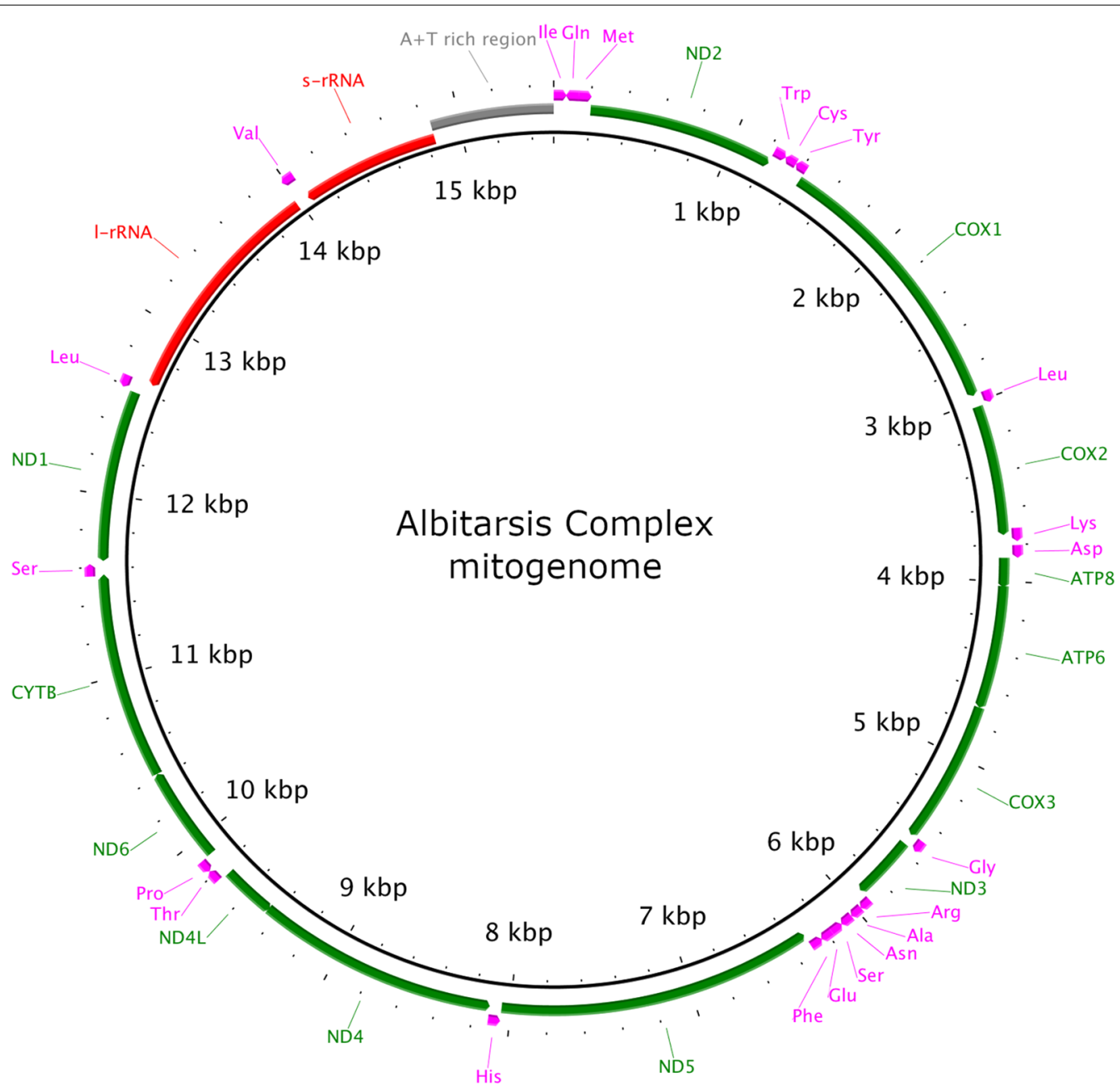

Fig. 2 Mitochondrial genome structure of the Albitarsis Complex mitogenome. All 13 protein-coding genes (green), 22 tRNA genes (pink), two rRNA genes (red), and the AT-rich control region (gray) are indicated. Arrows indicate the direction of transcription

polytomy in the mitogenome tree, was here found as a sister to a clade formed by all remaining species in the COI barcode tree. Within this sister clade, An. oryzalimnetes is sister to a clade containing the remaining species in this clade, and within this latter clade, An. albitarsis sensu stricto is sister to a multifurcating clade containing An. albitarsis $\mathrm{G}+$ An. albitarsis $\mathrm{H}+$ An. albitarsis $\mathrm{J}+$ An. deaneorum + An. marajoara. Within this clade, An. albitarsis $\mathrm{H}$, which formed a strongly supported clade in the mitogenome tree, fragmented into the polytomy.

\section{Species tree and species delimitation}

The joint species tree and species delimitation BPP analysis found a high degree of support for species designations in the Albitarsis Complex, but there was little information in the data to infer species phylogeny under a multispecies coalescent model. The differences between output produced from Algorithm 0 and Algorithm 1 and from varying $\mathrm{\tau}$ were also negligible (Table 1 ), and results described refer to those produced from Algorithm 0 and $\tau_{\text {med }}$. The posterior probability (PP) for all 10 species ranged from 0.88 to 0.95 (given range refers to $\theta_{\text {high }}-\theta_{\text {low }}$ ) and for nine species ranged from 0.05 to 0.12 . There were three alternative nine-species partitions, which merged An. albitarsis $\mathrm{F}$ with $A n$. albitarsis I ( $\mathrm{PP}=0.02-0.04)$, An. albitarsis J with An. albitarsis $\mathrm{H}(\mathrm{PP}=0.02-0.03)$, or An. albitarsis J with An. marajoara ( $\mathrm{PP}=0.01-0.05)$. Although the 10-species partition was therefore the most strongly supported, it did not exceed the $0.95 \mathrm{PP}$ threshold considered strong support for species splitting [68]. In addition, the uncertainty in the 10-species partition was due to the placement of An. albitarsis I and An. albitarsis J, both of which are represented by a single specimen. 


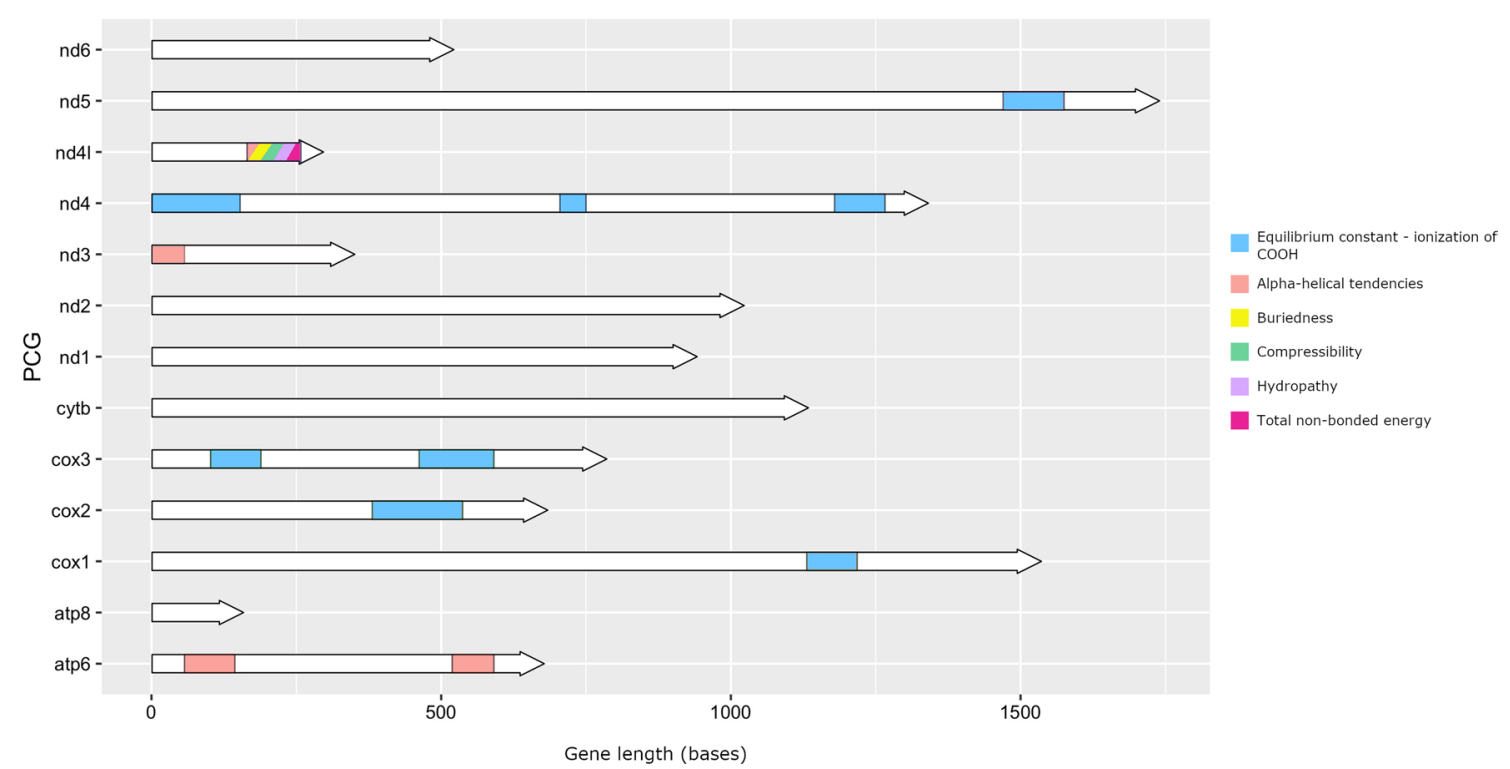

Fig. 3 TreeSAAP results showing regions among the 13 protein-coding genes under positive selection ( $P$-value $<0.001)$. Gene lengths are taken from sequence alignments

Species tree estimation provided a $95 \%$ credibility set of between 70 and 5151 unique species tree topologies (Table 1). The maximum a posteriori (MAP) species tree had a PP of just 0.03-0.33. The species tree is, therefore, highly uncertain under a model of multispecies coalescence, and the mitogenome appears to lack sufficient information to fully resolve the species phylogeny.
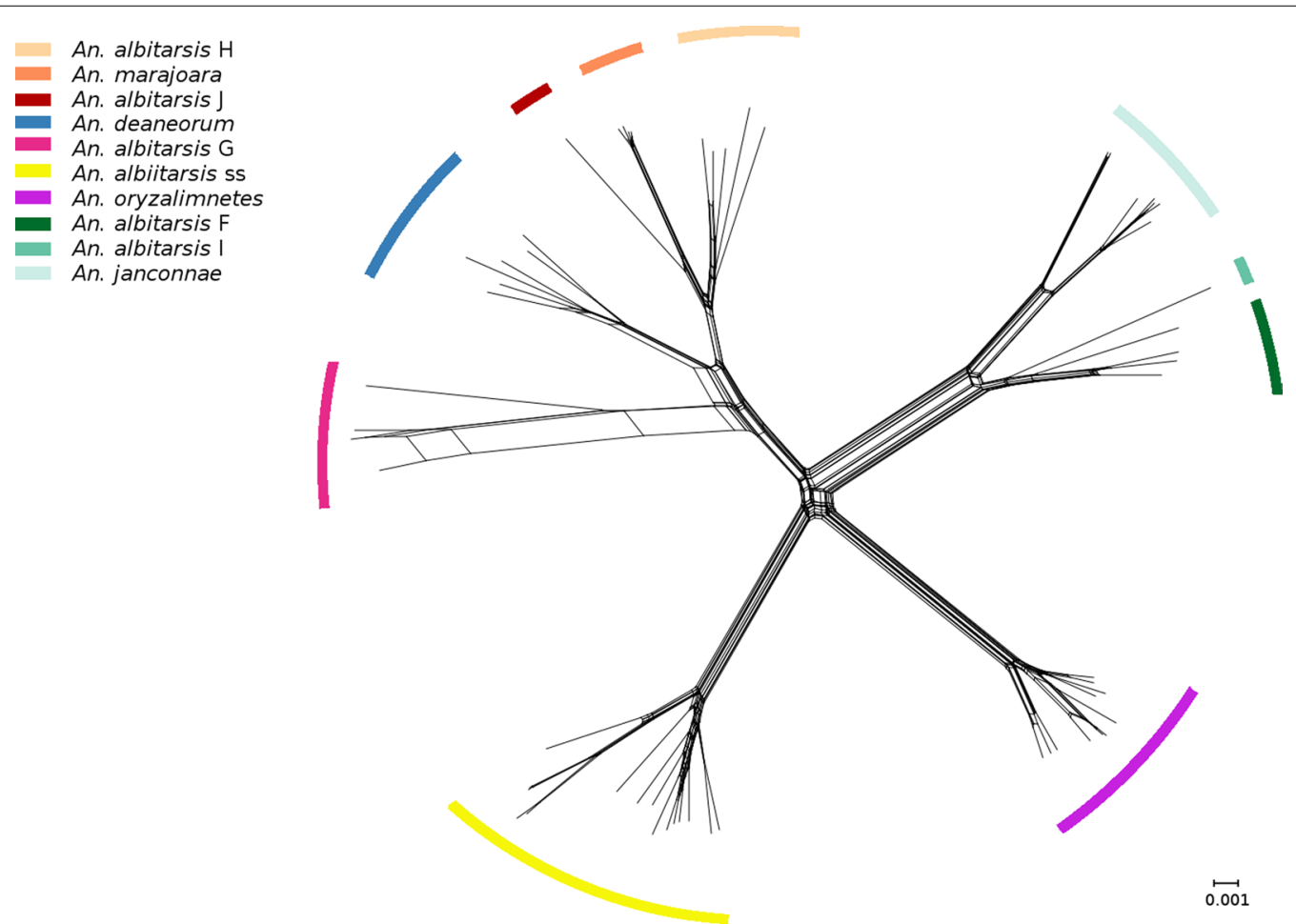

Fig. 4 SplitsTree (NeighborNet) network analysis of the 13 protein-coding genes of the Albitarsis Complex, showing the tree-like nature of the mitogenome data 


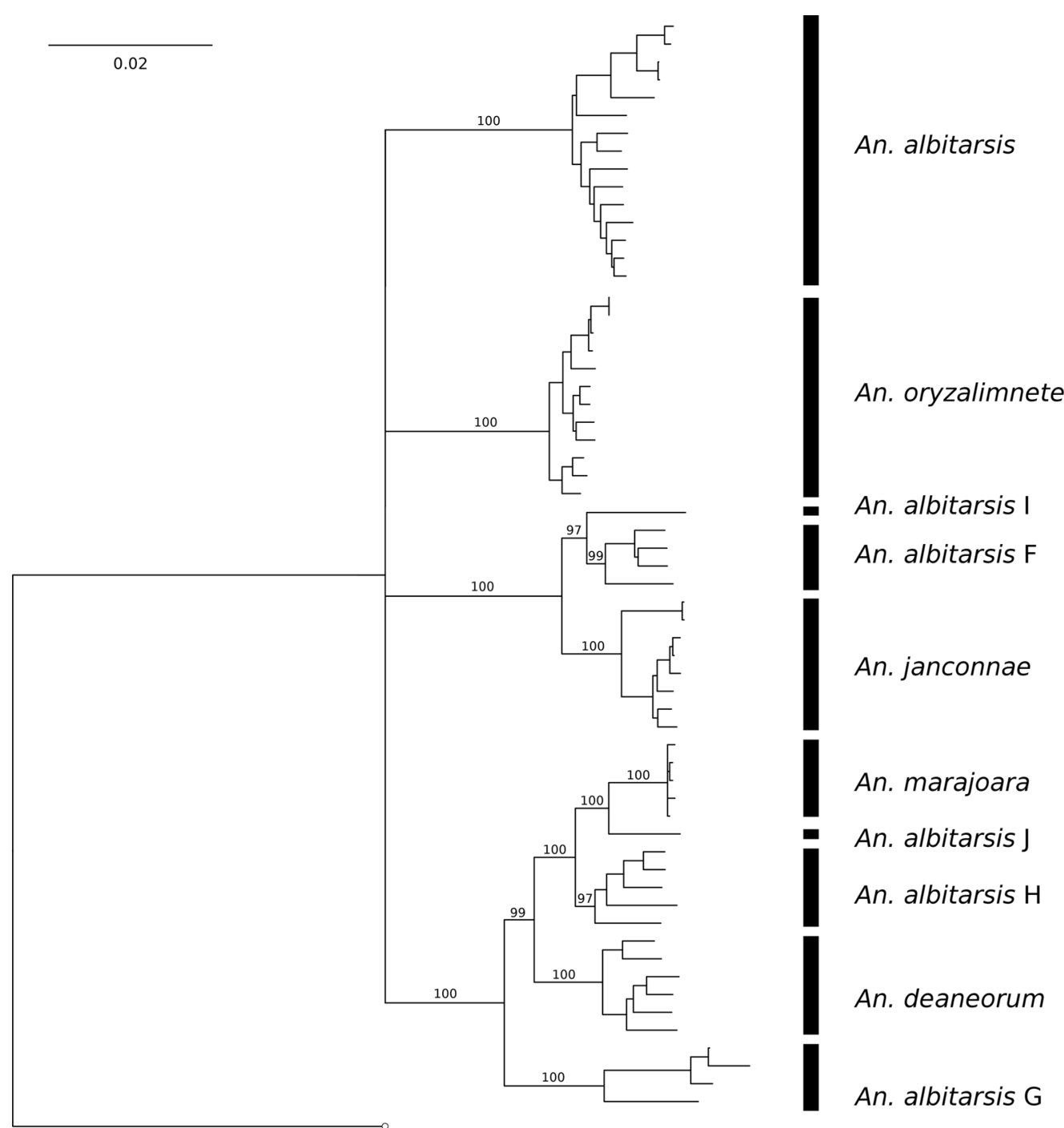

Fig. 5 Maximum likelihood (70\% majority-rule bootstrap consensus) gene tree of 13 PCGs from the Albitarsis Complex mitogenome. Bootstrap support is shown for each of the 10 members of the complex

A strict- and relaxed-clock species tree were construction in StarBEAST2 (Additional file 10: Figure S6; Additional file 11: Figure S7). For the relaxed-clock species tree, clock rate variation among branches was low (posterior branchRatesStdev.Species mean $<0.2$ ) and $95 \%$ highest posterior density (HPD) intervals for relative clock rates in all branches included 1, indicating the strict-clock species tree was more appropriate for this dataset. However, both clock models produced the same significantly supported (>70\% PP) clades, and similar divergence time estimates ( $<5 \%$ differences). The root of the Albitarsis Complex was dated to approximately 2.63 million years ago (mya: 95\% HPD: 1.90-3.19 mya; Table 2). The An. albitarsis F $+A n$. albitarsis $\mathrm{I}+$ An. janconnae clade is the only clade within the Albitarsis Complex found to reach moderate levels of support in the species tree (79\% PP). Divergence within this clade is dated to approximately 1.01 mya (95\% HPD: 0.64-1.35 mya; Table 2). All remaining splits in the species tree were insufficiently supported ( $<70 \% \mathrm{PP})$.

\section{Discussion}

Describing species diversity and relationships in the Albitarsis Complex is of great importance to malaria vector control initiatives in South America. Delivering targeted control measures, often with limited resources, relies on an ability to identify and incriminate vectors and discriminate them from benign relatives, and being cognizant of various biological processes, such as 


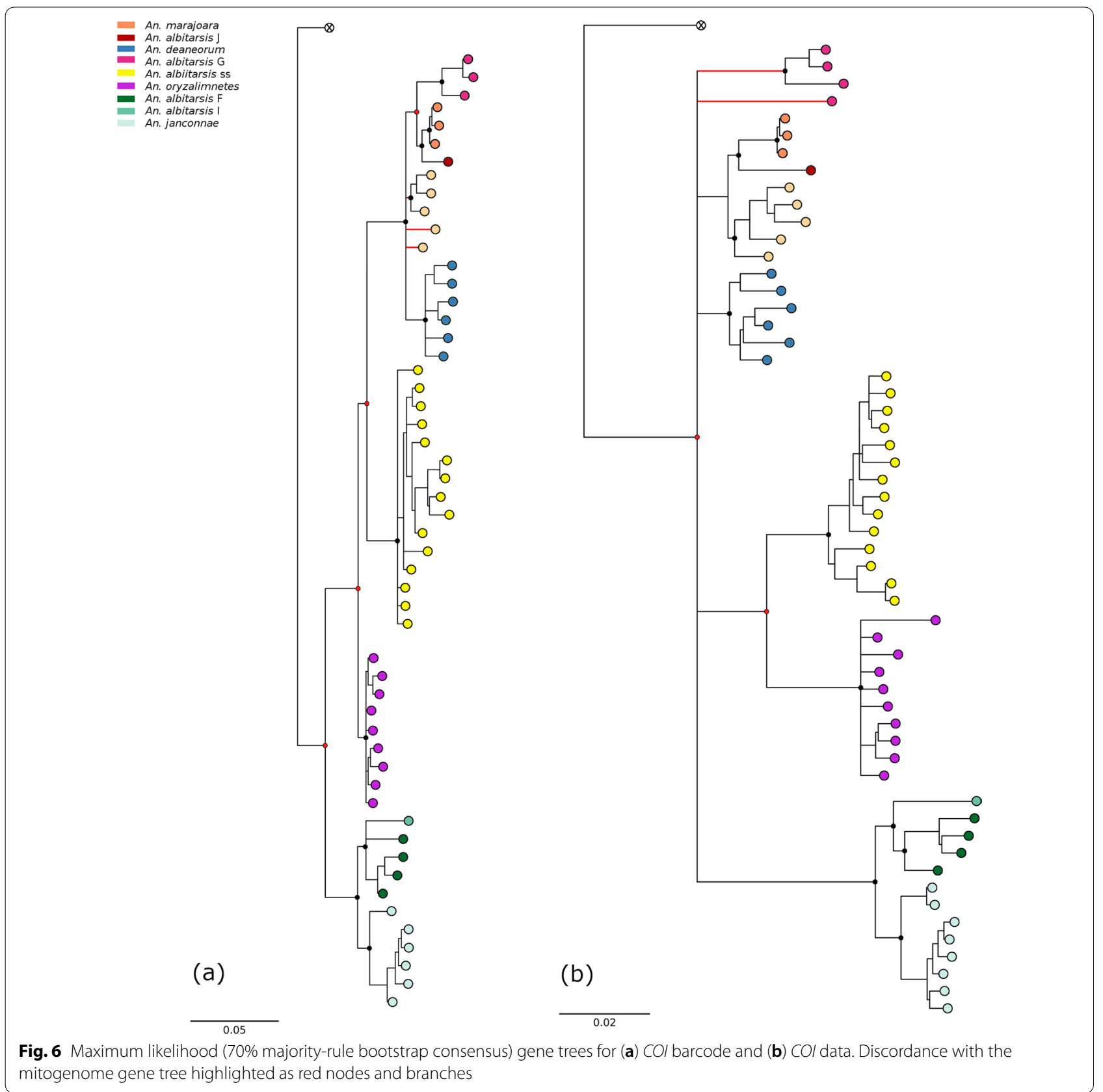

adaptive introgression, in vector complexes [69]. Additionally, understanding how diversity has been shaped by historical and ecological factors is not merely an academic exercise-it can provide important insights into how species of public health importance will respond to future events, such as deforestation, climate change, and rapid human population expansion. Here, we present a description of mitogenomic diversity in the Albitarsis Complex, and describe phylogenetic relationships among its species.
The gene composition and order of mitogenomes was conserved among species of the Albitarsis Complex, and was consistent with the architecture of mitogenomes from other species in the anopheline subgenera Nyssorhynchus (An. aquasalis) [37], Cellia (An. stephensi and An. dirus) [70], Kerteszia (An. bellator, An. cruzii, An. homunculus, and An. laneanus) [71] and Anopheles (An. sinensis) [72]. 
Table 1 BPP analysis that jointly estimates the species tree and species delimitation in the Albitarsis Complex

\begin{tabular}{|c|c|c|c|c|c|c|c|c|c|c|}
\hline \multicolumn{11}{|l|}{ Algorithm 0} \\
\hline \multicolumn{11}{|c|}{$\tau \sim \mid G(3,0.04)$} \\
\hline$\theta$ & 10-species & \multicolumn{2}{|c|}{ 9-species (total) } & \multicolumn{2}{|c|}{$\begin{array}{l}\text { 9-species } \\
\text { (albF-albl) }\end{array}$} & $\begin{array}{l}\text { 9-species } \\
\text { (albJ-albH) }\end{array}$ & $\begin{array}{l}\text { 9-species (albJ- } \\
\text { mara) }\end{array}$ & $\begin{array}{l}\text { Best tree } \\
\text { posterior } \\
\text { probability }\end{array}$ & MAP tree & No. trees \\
\hline $\mathrm{IG}(3,0.02)$ & 0.87 & \multicolumn{2}{|l|}{0.12} & \multicolumn{2}{|l|}{0.04} & 0.03 & 0.05 & $\begin{array}{l}0.03 \text { (10-spe- } \\
\text { cies) }\end{array}$ & $\begin{array}{l}\left(\left(\left(\left(a l b \_F, \text { alb_l), jan), }\right.\right.\right.\right. \\
(\text { alb_G, ((alb_H, (alb_J, } \\
\text { mara)), dean))), (alb, } \\
\text { ory)); }\end{array}$ & 4746 \\
\hline $\mathrm{IG}(3,0.01)$ & 0.92 & \multicolumn{2}{|l|}{0.08} & \multicolumn{2}{|l|}{0.04} & 0.02 & 0.02 & $\begin{array}{l}0.11 \text { (10-spe- } \\
\text { cies) }\end{array}$ & $\begin{array}{l}\left(\left(\left(\left(a l b \_F, \text { alb_ll), jan), }\right.\right.\right.\right. \\
(\text { alb, ory)), (alb_G, } \\
((\text { alb_H, (alb_J, mara)), } \\
\text { dean))); }\end{array}$ & 658 \\
\hline $\mathrm{G}(3,0.005)$ & 0.95 & \multicolumn{2}{|l|}{0.05} & 0.03 & & 0.01 & 0.01 & $\begin{array}{l}0.33 \text { (10-spe- } \\
\text { cies) }\end{array}$ & $\begin{array}{l}\left(\left(\left(\left(a l b \_F, \text { alb_ll), jan), }\right.\right.\right.\right. \\
(\text { alb, ory)), (alb_G, } \\
((\text { alb_H, (alb_J, mara)) } \\
\text { dean))); }\end{array}$ & 73 \\
\hline \multicolumn{11}{|c|}{$\tau \sim I G(3,0.05)$} \\
\hline$\theta$ & 10-species & \multicolumn{3}{|c|}{ 9-species (total) } & $\begin{array}{l}\text { 9-species } \\
\text { (albF-albl) }\end{array}$ & $\begin{array}{l}\text { 9-species } \\
\text { (albJ-albH) }\end{array}$ & $\begin{array}{l}\text { 9-species } \\
\text { (albJ-mara) }\end{array}$ & \multicolumn{2}{|l|}{$\begin{array}{l}\text { Best tree } \\
\text { posterior } \\
\text { probability }\end{array}$} & No. trees \\
\hline $\operatorname{IG}(3,0.02)$ & 0.88 & \multicolumn{3}{|c|}{0.12} & 0.04 & 0.03 & 0.05 & 0.03 & $\begin{array}{l}\left(\left(\left(\left(a l b \_F, a l b \_l\right), j a n\right),(a l b,\right.\right. \\
\text { ory)),(alb_G, ((alb_H, } \\
\text { (alb_J, mara)), dean))); }\end{array}$ & 4731 \\
\hline $\mathrm{IG}(3,0.01)$ & 0.92 & \multicolumn{3}{|c|}{0.08} & 0.03 & 0.03 & 0.02 & 0.11 & $\begin{array}{l}\text { ((((alb_F, alb_l), jan), (alb, } \\
\text { ory)), (alb_G, ((alb_H, } \\
\text { (alb_J, mara)), dean))); }\end{array}$ & 550 \\
\hline $\mathrm{IG}(3,0.005)$ & 0.95 & \multicolumn{3}{|c|}{0.05} & 0.02 & 0.02 & 0.01 & 0.30 & $\begin{array}{l}\text { ((((alb_F, alb_l), jan), (alb, } \\
\text { ory)), (alb_G, ((alb_H, } \\
\text { (alb_J, mara)), dean))); }\end{array}$ & 78 \\
\hline$\tau \sim I G(3,0.0$ & & & & & & & & & & \\
\hline$\theta$ & 10-species & & 9-species & (total) & $\begin{array}{l}\text { 9-species } \\
\text { (albF-albl) }\end{array}$ & $\begin{array}{l}\text { 9-species } \\
\text { (albJ-albH) }\end{array}$ & $\begin{array}{l}\text { 9-species } \\
\text { (albJ-mara) }\end{array}$ & $\begin{array}{l}\text { Best tree } \\
\text { posterior } \\
\text { probability }\end{array}$ & & No. trees \\
\hline $\mathrm{IG}(3,0.02)$ & 0.88 & & 0.12 & & 0.05 & 0.03 & 0.04 & 0.03 & $\begin{array}{l}\left(\left(\left(\left(a l b \_F, \text { alb_l), jan), (alb_G, }\right.\right.\right.\right. \\
\left(\left(a l b \_H,\left(a l b \_J, \text { mara) }\right), \text { dean))), }\right.\right. \\
\text { (alb, ory)); }\end{array}$ & 4894 \\
\hline $\mathrm{IG}(3,0.01)$ & 0.92 & & 0.08 & & 0.03 & 0.03 & 0.02 & 0.10 & $\begin{array}{l}((((\text { alb_F, alb_l), jan), (alb, ory)), } \\
\text { (alb_G, ((alb_H, (alb_J, mara)), } \\
\text { dean))); }\end{array}$ & 693 \\
\hline $\mathrm{IG}(3,0.005)$ & 0.95 & & 0.05 & & 0.02 & 0.02 & 0.01 & 0.32 & $\begin{array}{l}\left(\left(\left(\left(a l b \_F, \text { alb_l), jan), (alb, ory)), }\right.\right.\right.\right. \\
\text { (alb_G, ((alb_H, (alb_J, mara)), } \\
\text { dean))); }\end{array}$ & 171 \\
\hline Algorithm 1 & & & & & & & & & & \\
\hline$\tau \sim \mid \mathrm{G}(3,0.0$ & & & & & & & & & & \\
\hline$\theta$ & 10-species & & $\begin{array}{l}\text { 9-species } \\
\text { (total) }\end{array}$ & & $\begin{array}{l}\text { species } \\
\text { |bF-alb|) }\end{array}$ & $\begin{array}{l}\text { 9-species } \\
\text { (albJ-albH) }\end{array}$ & $\begin{array}{l}\text { 9-species } \\
\text { (albJ-mara) }\end{array}$ & $\begin{array}{l}\text { Best tree } \\
\text { posterior } \\
\text { probability }\end{array}$ & & \\
\hline $\operatorname{IG}(3,0.02)$ & 0.88 & & 0.12 & & .04 & 0.02 & 0.04 & 0.03 & $\begin{array}{l}\left(\left(\left(\left(a l b \_F, \text { alb_ll), jan), }\right.\right.\right.\right. \\
\text { (alb_G, ((alb_H, (alb_J, } \\
\text { mara)), dean))), (alb, } \\
\text { ory)); }\end{array}$ & \\
\hline $\mathrm{IG}(3,0.01)$ & 0.92 & & 0.08 & & .04 & 0.02 & 0.02 & 0.11 & $\begin{array}{l}\left(\left(\left(\left(a l b \_F, \text { alb_ll),jan), }\right.\right.\right.\right. \\
\text { (alb, ory)), (alb_G, } \\
((\text { alb_H, (alb_J, mara)), } \\
\text { dean))); }\end{array}$ & \\
\hline
\end{tabular}


Table 1 (continued)

\begin{tabular}{|c|c|c|c|c|c|c|c|c|c|}
\hline \multicolumn{10}{|l|}{ Algorithm 1} \\
\hline \multicolumn{10}{|c|}{$\tau \sim \operatorname{IG}(3,0.04)$} \\
\hline$\theta$ & 10-species & $\begin{array}{l}\text { 9-species } \\
\text { (total) }\end{array}$ & $\begin{array}{l}\text { 9-species } \\
\text { (albF-albl) }\end{array}$ & $\begin{array}{l}\text { 9-species } \\
\text { (albJ-albH) }\end{array}$ & $\begin{array}{l}\text { 9-species } \\
\text { (albJ-mara) }\end{array}$ & \multicolumn{4}{|c|}{$\begin{array}{l}\text { Best tree } \\
\text { posterior } \\
\text { probability }\end{array}$} \\
\hline $\mathrm{IG}(3,0.005)$ & 0.95 & 0.05 & 0.02 & 0.02 & 0.01 & 0.31 & & $\begin{array}{l}\text { F, alb_l), jan), } \\
\text { (y)), (alb_G, } \\
\text {,, (alb_J, mara)), } \\
f_{i}\end{array}$ & 79 \\
\hline \multicolumn{10}{|c|}{$\tau \sim \operatorname{IG}(3,0.05)$} \\
\hline$\theta$ & 10-species & $\begin{array}{l}\text { 9-species } \\
\text { (total) }\end{array}$ & $\begin{array}{l}\text { 9-species } \\
\text { (albF-albl) }\end{array}$ & $\begin{array}{l}\text { 9-species } \\
\text { (albJ-albH) }\end{array}$ & \multicolumn{2}{|c|}{$\begin{array}{l}\text { 9-species } \\
\text { (albJ-mara) }\end{array}$} & \multicolumn{2}{|l|}{$\begin{array}{l}\text { Best tree } \\
\text { posterior } \\
\text { probability }\end{array}$} & No. trees \\
\hline $\mathrm{IG}(3,0.02)$ & 0.88 & 0.12 & 0.04 & 0.02 & \multicolumn{2}{|l|}{0.05} & 0.03 & $\begin{array}{l}\left(\left(\left(\left(a l b \_F, a l b \_l\right),\right.\right.\right. \\
\text { jan), (alb, } \\
\text { ory)), (alb_G, } \\
((\text { alb_H, (alb_J, } \\
\text { mara)), dean))); }\end{array}$ & 5151 \\
\hline $\mathrm{IG}(3,0.01)$ & 0.93 & 0.07 & 0.03 & 0.02 & \multicolumn{2}{|l|}{0.02} & 0.11 & $\begin{array}{l}\left(\left(\left(\left(a l b \_F, \text { alb_l), }\right.\right.\right.\right. \\
\text { jan), (alb, } \\
\text { ory)), (alb_G, } \\
((\text { alb_H, (alb_J, } \\
\text { mara)), dean))); }\end{array}$ & 738 \\
\hline $\mathrm{IG}(3,0.005)$ & 0.95 & 0.05 & 0.02 & 0.01 & \multicolumn{2}{|l|}{0.01} & 0.32 & $\begin{array}{l}\left(\left(\left(\left(a l b \_F, a l b \_l\right),\right.\right.\right. \\
\text { jan), (alb, } \\
\text { ory)), (alb_G, } \\
((\text { alb_H, (alb_J, } \\
\text { mara)), dean))); }\end{array}$ & 70 \\
\hline \multicolumn{10}{|c|}{$\tau \sim \operatorname{IG}(3,0.06)$} \\
\hline$\theta$ & 10-species & $\begin{array}{l}\text { 9-species } \\
\text { (total) }\end{array}$ & $\begin{array}{l}\text { 9-species } \\
\text { (albF-albl) }\end{array}$ & $\begin{array}{l}\text { 9-species } \\
\text { (albJ-albH) }\end{array}$ & \multicolumn{2}{|c|}{$\begin{array}{l}\text { 9-species } \\
\text { (albJ-mara) }\end{array}$} & \multicolumn{2}{|l|}{$\begin{array}{l}\text { Best tree } \\
\text { posterior } \\
\text { probability }\end{array}$} & No. trees \\
\hline $\mathrm{IG}(3,0.02)$ & 0.88 & 0.12 & 0.04 & 0.02 & \multicolumn{2}{|l|}{0.04} & 0.03 & $\begin{array}{l}\left(\left(\left(\left(a l b \_F, \text { alb_l), }\right.\right.\right.\right. \\
\text { jan), (alb, } \\
\text { ory)), (alb_G, } \\
((\text { alb_H, (alb_J, } \\
\text { mara)), dean))); }\end{array}$ & 4792 \\
\hline $\mathrm{IG}(3,0.01)$ & 0.92 & 0.08 & 0.03 & 0.02 & \multicolumn{2}{|l|}{0.02} & 0.11 & $\begin{array}{l}\left(\left(\left(\left(a l b \_F, a l b \_l\right),\right.\right.\right. \\
\text { jan), (alb, } \\
\text { ory)), (alb_G, } \\
((\text { alb_H, (alb_J, } \\
\text { mara)), dean))); }\end{array}$ & 686 \\
\hline $\mathrm{IG}(3,0.005)$ & 0.95 & 0.05 & 0.02 & 0.01 & \multicolumn{2}{|l|}{0.01} & 0.31 & $\begin{array}{l}\left(\left(\left(\left(a l b \_F, \text { alb_l), }\right.\right.\right.\right. \\
\text { jan), (alb, } \\
\text { ory)), (alb_G, } \\
((\text { alb_H, (alb_J, } \\
\text { mara)), dean))); }\end{array}$ & 75 \\
\hline
\end{tabular}

$\tau=$ mean root age, specified by an inverse-gamma prior IG $(a, b)$. Mean $=b /(a-1)$

$\theta=$ mean genetic diversity, specified by an inverse-gamma prior $\mathrm{IG}(a, b)$. Mean $=b /(a-1)$

Best tree $=$ maximum a posteriori (MAP) species tree

No. trees $=$ number of trees in the $95 \%$ credibility set

We found only signatures of positive selection among genes in the mitogenome. The most widespread of these were changes to the equilibrium constant in two ND genes and all COX genes, which are associated with complexes I and IV of the oxidative phosphorylation (OXPHOS) system, respectively, and its various cellular functions and metabolic processes. However, in the current study we considered only property changes 
Table 2 Estimated divergence times in the Albitarsis Complex from StarBEAST2 analysis

\begin{tabular}{llll}
\hline Clade & Age, mean (mya) & $\begin{array}{l}\text { Age, 95\% HPD } \\
\text { (mya) }\end{array}$ & $\begin{array}{l}\text { Posterior } \\
\text { support } \\
(\%)\end{array}$ \\
\hline $\begin{array}{l}\text { Albitarsis Complex } \\
\begin{array}{l}\text { An.janconnae+An. } \\
\text { albitarsis F+An. }\end{array}\end{array}$ & 1.01 & $1.90-3.19$ & 100 \\
albitarsis I & $0.64-1.35$ & 79 \\
\hline
\end{tabular}

that could be mapped to internal branches of the mitogenome tree to be true candidate variants under positive selection, as property changes at terminal tips may represent deleterious changes prior to the action of purifying selection. Increased chromatographic index and polarity properties were mapped to the $A n$. janconnae and An. albitarsis $\mathrm{G}$ clades, respectively. These properties have the potential to influence residue water solubility and reactive oxygen species (ROS) production, which can influence an organism's longevity and immune response [73-75] and defense against viral and microbial pathogens [76, 77]. Such positive selection may have played an important role in the rapid diversification and adaptation in the complex, which occurred across much of the southern Americas over a comparatively short period of time. It may also have been an important adaptive response to infection by pathogens such as Plasmodium, which is believed to reduce mosquito survival [78].

The mitogenome gene tree constructed in this study supported the resolution of all 10 members of the Albitarsis Complex, a finding that is largely consistent with the COI barcode clustering of Motoki et al. [11] and Ruiz et al. [7]. Although mitogenomic genes are expected to share the same evolutionary tree, we may expect to see topological variation among gene trees due to systematic error (as opposed to biological process), and we observe this in the gene trees from this study and among other studies [7, 11]. An important feature of the mitogenome gene tree is the basal polytomy, which contains four main clades. This is likely a soft polytomy, attributable to the considerable diversification that occurred over a short period of time and the insufficient information in the data to resolve the branching order. All clades derived from this four-way polytomy are very highly supported. Considerable differences are found between this tree and the $C O I$ and $C O I$ barcode gene trees, where some putative species (An. albitarsis G and An. albitarsis $\mathrm{H})$ fragment into polytomies, and topological conflict is found at higher levels in the trees. Differences can also be seen in comparisons to the findings of other studies. The Bayesian COI tree of Ruiz et al. [7] displays several differences when only strongly supported branches are considered (i.e., a four-way polytomy in the An. albitarsis $\mathrm{G}+A n$. albitarsis $\mathrm{H}+A n$. deaneorum + An. marajoara clade), while the COI tree of Motoki et al. [11] recovers An. albitarsis $\mathrm{H}$ as a strongly supported sister taxon to An. deaneorum, in contrast to the mitogenome gene tree, which finds it to be a sister of the An. marajoara $+A n$. albitarsis J clade. Given these findings, although $C O I$ and $C O I$ barcode data are routinely used for species delimitation analyses, it appears that these data do not effectively recovery the topology of the Albitarsis Complex mitogenome gene tree.

A highly important consideration when inferring the evolutionary relationships of recently diverged species is to account for the retention of ancestral polymorphism or incomplete lineage sorting, which creates discordance between gene trees and species trees. This discordance becomes more pronounced when divergence times are short relative to the effective population sizes [79], as is likely the case in our study. Our main phylogenetic inferences for species in the complex therefore relied on the multispecies coalescent model, which provides more accurate assessment of uncertainty in the species tree estimate and better estimates of species divergence times, while accounting for incomplete lineage sorting.

Due to the comparatively recent evolutionary history of the Albitarsis Complex, we were unable to use appropriate geologically dated fossils or phylogeographical events to establish an absolute timescale for divergence. The fossil record for mosquitoes is particularly scant. Only two fossil anopheline mosquitoes, An. (Nyssorhynchus?) dominicanus and An. (?) rottensi, currently exist and date from approximately $15-45$ mya and 25 mya, respectively $[80,81]$. We therefore used the mitochondrial DNA clock of Brower [65], derived from South American Heliconius butterflies. We considered Brower's [65] estimate to be suited to our study as it was based on calibration points since the late Pliocene (i.e., comparable to our study's timescale), and on a range of fast and slow genes from across the mitogenome. Papadopoulou et al. [82] found that their mitochondrial substitution rate for Coleoptera, which used older calibration points, was also comparable to that of Brower [65]. However, we recognize and here underline the importance of undertaking further work which seeks to test the utility of this clock at lower levels in Anopheles using temporally appropriate calibration points from geological, biogeographical, and/or paleoclimatic data. 
Unfortunately, there was insufficient information in the mitogenome to provide strongly supported divergence estimates among most species in the Albitarsis Complex. While the inability to resolve basal relationships in the species tree was also found in the mitogenome gene tree, the former also displays a considerable amount of uncertainty at lower levels of the species tree. Despite these shortcomings, the initial radiation of the Albitarsis Complex could be dated to approximately 2.63 mya, or around the Pliocene/Pleistocene boundary (2.58 mya; [83]). It appears plausible that the comparatively recent origin of this diverse (putatively 10 species) complex required some degree of adaptation to the considerable climatic and environmental changes occurring from the late Pliocene [84] through to the late Pleistocene [85] on the continent. Our detection of positive selection in some species appears to support this. Our estimates for divergence in the Albitarsis Complex were not explained by marine incursions, which occurred no later than the end of the Miocene, approximately 5.33 mya [86]. It has been suggested that the Amazon River may have played an important role in driving the initial radiation in the complex [19]. According to our findings, the Amazon River barrier hypothesis also does not in itself explain this radiation, as the formation of the Amazon River, approximately 5-12 mya, predates initial diversification in the complex by at least approximately 2 million years. It is possible that the Amazon River acted as a subsequent barrier to the range expansion of locally adapted populations from either side of the river. However, the strength of these claims relies on the ability of the Amazon River to act as a barrier to dispersal and gene flow. The fact that all species inhabiting the banks of the Amazon, with the exception of An. albitarsis J, have now been collected on both sides of the river (shown for An. janconnae and An. marajoara in Motoki et al. [11], and for An. albitarsis G and $A n$. oryzalimnetes in McKeon et al. [39]) would appear to refute these hypotheses, although human-aided transport across the Amazon River cannot yet be excluded as a possible explanation for these occurrences.

Our findings suggest that divergence in the An. albitarsis $\mathrm{F}+A n$. albitarsis $\mathrm{I}+$ An. janconnae clade began between 0.64 and 1.35 mya. This period was also highly important in shaping interspecific diversification in other mosquito complexes (Nuneztovari Complex) [87] and forest birds [88] and intraspecific clade diversification in forest species of amphibians [89], birds [90], and mammals [91] in northern South America. One of the species that emerged, An. janconnae, is an important malaria vector [18] and appears to have undergone considerable adaptation during this period, displaying signatures of positive selection in the mitogenome and comparatively strong habitat specialization, seeking larval habitats with low sun exposure and high water velocities [92].

Although our study does not reject the 10-member Albitarsis Complex hypothesis, it should be noted that the multispecies coalescent approach, along with delimiting species boundaries, may also detect population splits [93]. So, while our delimitation approach provides further support for those formally recognized species in the complex [27], the delimitation of the four putative species (An. albitarsis G, H, I, and J) for which no extramitogenomic information exists cannot be considered as clear support for their species status. To date, four of the 10 members of the Albitarsis Complex have been defined on the basis of COI data only. Anopheles albitarsis G (An. marajoara lineage 2 in McKeon et al. [39]), Anopheles albitarsis $\mathrm{J}$ (found as the $\mathrm{C} 3+\mathrm{C} 4+\mathrm{C} 5$ clade in Lehr et al. [32] and included in McKeon et al. [39]), and An. albitarsis I (denoted "near An. janconnae" in Gutiérrez et al. [36]) are resolved at the mitochondrial COI gene, but not at the nuclear white or ITS2 genes [7, 11, 36, 39], while An. albitarsis $\mathrm{H}$ has only ever been analyzed and resolved at the $\mathrm{COI}$ gene [7]. Examination of GenBank COI data shows that minimum interspecific pairwise distances for these four putative species are extremely low (An. albitarsis H KJ492691 and An. albitarsis J DQ076220 =1.21\% K2P distance; An. albitarsis J JQ615466 and An. marajoara JQ615442 =1.55\%; An. albitarsis I JQ615193 and An. albitarsis $\mathrm{F}$ JQ615020 $=2.02 \%)$, and many do not exceed their maximum intraspecific pairwise distance (An. albitarsis H JQ615154 and KJ492402=2.00\%; An. albitarsis F JQ615005 and JQ615009=2.66\%). Additionally, in our study, An. albitarsis I and An. albitarsis J are each represented by only a single mitogenome, which is likely to have affected population size estimates in the multispecies coalescent construction of the species tree and delimitation. These species also have the lowest levels of delimitation support, primarily due to the albeit poor support for merging of An. albitarsis I with An. albitarsis $\mathrm{F}$ and An. albitarsis J with An. albitarsis $\mathrm{H}$ or An. marajoara. Given the lack of external (extra-mitogenomic) support to form a strong a priori species hypothesis for An. albitarsis G, An. albitarsis $\mathrm{H}, A n$. albitarsis $\mathrm{I}$, and An. albitarsis J, and the scant sampling of the latter two in the current study, these putative species require particular attention in future studies. These should employ genomic data to discriminate potential population splits from species divergence and be supported by an analysis of morphological and/or ecological datasets before any firm conclusions can be drawn on species designation.

While our study provides important insights into mitogenome architecture, signatures of selection, and the origin and nature of diversification, it also found a considerable 
degree of uncertainty around the phylogeny of the Albitarsis Complex. A more complete understanding of the origins and diversification of the complex will undoubtedly require genome-wide data, which may help resolve the basal uncertainty, estimate the lower-level branching order, and identify those genomic regions under selection driving incipient speciation. Explaining the origins and nature of species diversity in this complex will also require a much better understanding of the geographical distribution and putative boundaries among its species. Further sampling of its members from prospective habitats, particularly for those flanking the Amazon River, is clearly desirable for more robust testing of biogeographical hypotheses. A comparative study of species radiation in the Nyssorhynchus mosquito complexes found across northern South America-which include the Albitarsis Complex, Nuneztovari Complex [94], Oswaldoi-Konderi Complex [95], and those from the Strodei Subgroup [96, 97] - would also be a timely and valuable contribution to understanding the main biogeographical and evolutionary factors driving diversification across many of the most important malaria vectors on the continent.

\section{Conclusions}

These analyses of Albitarsis Complex mitogenomes detected conserved mitogenomic architecture across species as well as signatures of positive selection in Anopheles janconnae and An. albitarsis G, which may have played a role in the recent and rapid diversification in the Albitarsis Complex. Although considerable uncertainty was found among branching events in trees, the origin of divergence in the Albitarsis Complex was dated to the Pliocene/Pleistocene boundary, approximately 2.63 mya, and divergence within the distinct northern South American clade, comprising An. albitarsis F, An. albitarsis I, and An. janconnae, was estimated at approximately 1 mya. Our findings show that a 10-species hypothesis for the Albitarsis Complex cannot be rejected, but further analysis of the complex using genome-wide data and the inclusion of additional specimens of lesser studied (and as yet still informal) taxa is recommended to further elucidate the origins and diversification of this important assemblage.

\footnotetext{
Abbreviations

BPP: Bayesian Phylogenetics and Phylogeography; COl: Mitochondrial cytochrome c oxidase l; COX: Mitochondrial cytochrome c oxidase; DTT: Dithiothreitol; FCLM: Four-cluster likelihood mapping; MAP: Maximum a posteriori; Mya: Million years ago; ND1-ND6: Nicotinamide adenine dinucleotide dehydrogenase subunit 1-6; PCG: Protein-coding genes; PCR: Polymerase chain reaction; rjMCMC: Reversible-jump Markov chain Monte Carlo; ROS: Reactive oxygen species; rRNA: Ribosomal ribonucleic acid; SDS: Sodium dodecyl sulphate; SEEVA: Spatial evolutionary and ecological vicariance analysis; tRNA: Transfer ribonucleic acid.
}

\section{Supplementary Information}

The online version contains supplementary material available at https://doi. org/10.1186/s13071-021-05090-w.

Additional file 1: Table S1. Geographical origin of the Albitarsis Complex specimens examined in this study.

Additional file 2: Table S2. Base composition (\% AT content) of the Albitarsis Complex mitogenome, and additional species from the genus.

Additional file 3: Table S3. Substitution saturation tests for the third codon position of the 13 PCGs from the Albitarsis Complex mitogenome.

Additional file 4: Table S4. Organization, features and alignment statistics of the 13 PCGs, 22 tRNAs and 2 rRNAs from the Albitarsis Complex mitogenome.

Additional file 5: Figure S1. SplitsTree (NeighborNet) network analysis of the 13 protein-coding genes and two rRNA genes of the Albitarsis Complex, showing the tree-like nature of the mitogenome.

Additional file 6: Figure S2. Four-cluster likelihood mapping of the 13 PCGs of the Albitarsis Complex, showing the tree-like nature of the mitogenome data.

Additional file 7: Figure S3. Four-cluster likelihood mapping of the 13 protein-coding genes and two rRNA genes of the Albitarsis Complex, showing the tree-like nature of the mitogenome data.

Additional file 8: Figure S4. Maximum likelihood (70\% majority-rule bootstrap consensus) gene tree of 13 PCGs and two rRNAs from the Albitarsis Complex mitogenome. Bootstrap support is shown for each of the 10 members of the complex.

Additional file 9: Figure S5. Maximum likelihood (70\% majority-rule bootstrap consensus) gene tree of (a) PCGs and (b) PCGs and rRNAs from the Albitarsis Complex mitogenome, with the fastest sites removed (Tiger alignments).

Additional file 10: Figure S6. Species tree of the 13 PCGs of the Albitarsis Complex under a strict-clock model.

Additional file 11: Figure S7. Species tree of the 13 PCGs of the Albitarsis Complex under a relaxed-clock (UCLN) model.

\section{Acknowledgements}

We are grateful to Fredy Ruiz-Lopez, Maria Anice Sallum, Maysa Motoki, and Jan E. Conn, among others, for sample collection under funding from the US National Institutes of Health grant R01 Al50139-02 (to Jan E. Conn) and from the Foundation for Research Support of the State of São Paulo, FAPESP (Process no. 2011/20397-7 to Maria Anice Sallum). This research was performed under a Memorandum of Understanding between the Walter Reed Army Institute of Research and the Smithsonian Institution, with institutional support provided by both organizations. The published material reflects the views of the authors and should not be construed to represent those of the Department of the Army or the Department of Defense.

\section{Authors' contributions}

$B P B$ and YML conceived and designed the study. Collectively BPB, RCW, LCQ YML, SAJ and DBP collected, curated and/or sequenced samples. BPB performed mitogenome assembly, annotation and analyses. BPB and YML wrote the manuscript. All authors reviewed, read and approved the final manuscript.

\section{Funding}

This study was conducted while BPB and SAJ held National Research Council Research Associateships at the Walter Reed Biosystematics Unit and Walter Reed Army Institute of Research. The study was funded by the US Military Infectious Disease Research Program (MIDRP) (MI210081 to YML) and through core support to WRBU by the Armed Forces Health Surveillance Division (AFHSD)_Global Emerging Infections Surveillance (GEIS) Branch (P0030_21_ WR to YML). 


\section{Availability of data and materials}

The Albitarsis Complex mitogenome data that support the findings of this study are available in GenBank, https://www.ncbi.nlm.nih.gov/genbank (MT588297, MW915567, MZ062449-MZ062481).

\section{Declarations}

Ethics approval and consent to participate

Not applicable.

\section{Consent for publication}

Not applicable.

\section{Competing interests}

The authors declare that they have no competing interests.

\section{Author details}

'Walter Reed Biosystematics Unit, Smithsonian Institution Museum Support Center, MRC-534, 4210 Silver Hill Rd., Suitland, MD 20746, USA. ${ }^{2}$ Walter Reed Army Institute of Research, 503 Robert Grant Avenue, Silver Spring, MD 20910 USA. ${ }^{3}$ Department of Entomology, Smithsonian Institution-National Museum of Natural History, 10th St NE \& Constitution Ave NE, Washington, DC 20002, USA

Received: 3 August 2021 Accepted: 8 November 2021 Published online: 27 November 2021

\section{References}

1. World Health Organization. Fact sheet: vector-borne diseases. 2020 https://www.who.int/en/news-room/fact-sheets/detail/vector-bornediseases. Accessed 28 May 2020.

2. World Health Organization. World Malaria Report 2019. 2019. https:// apps.who.int/iris/handle/10665/330011. Accessed 20 May 2021.

3. White NJ. Plasmodium knowlesi: the fifth human malaria parasite. Clin Infect Dis. 2008;46(2):172-3.

4. Kantele A, Jokiranta TS. Review of cases with the emerging fifth human malaria parasite, Plasmodium knowlesi. Clin Infect Dis. 2011:52(11):1356-62.

5. Sinka ME, Rubio-Palis Y, Manguin S, Patil AP, Temperley WH, Gething PW, et al. The dominant Anopheles vectors of human malaria in the Americas: occurrence data, distribution maps and bionomic précis. Parasit Vectors. 2010;3:72

6. Conn JE, Ribolla PE. Ecology of Anopheles darlingi, the primary malaria vector in the Americas and current nongenetic methods of vector control. In: Genetic control of malaria and dengue. 2016. p. 81-102.

7. Ruiz-Lopez F, Wilkerson RC, Conn JE, McKeon SN, Levin DM, et al. DNA barcoding reveals both known and novel taxa in the Albitarsis Group (Anopheles: Nyssorhynchus) of Neotropical malaria vectors. Parasit Vectors. 2012:5:44

8. Lardeux F, Chávez T, Rodríguez R, Torrez L. Anopheles of Bolivia: new records with an updated and annotated checklist. Comptes Rendus Biol. 2009;332(5):489-99.

9. Wilkerson RC, Gaffigan TV, Bento LJ. Identification of species related to Anopheles (Nyssorhynchus) albitarsis by random amplified polymorphic DNA-polymerase chain reaction (Diptera: Culicidae). Mem Inst Oswaldo Cruz. 1995;90(6):721-32.

10. Dusfour I, Jarjaval F, Gaborit P, Mura M, Girod R, Pagès F. Confirmation of the occurrence of Anopheles (Nyssorhynchus) marajoara in French Guiana. J Am Mosq Control Assoc. 2012;28(4):309-11.

11. Motoki MT, Linton Y-M, Conn JE, Ruiz-Lopez F, Wilkerson RC. Phylogenetic network of mitochondrial COI gene sequences distinguishes 10 taxa within the Neotropical Albitarsis Group (Diptera: Culicidae), confirming the separate species status of Anopheles albitarsis H (Diptera: Culicidae) and revealing a novel lineage, Anopheles albitarsis. J J Med Entomol. 2021;58(2):599-607.

12. Galardo AKR, Arruda M, Couto AARD, Wirtz R, Lounibos LP, Zimmerman $\mathrm{RH}$. Malaria vector incrimination in three rural riverine villages in the Brazilian Amazon. Am J Trop Med Hyg. 2007;76(3):461-9.
13. Conn JE, Wilkerson RC, Segura MNO, de Souza RTL, Schlichting CD, Wirtz $R A$, et al. Emergence of a new neotropical malaria vector facilitated by human migration and changes in land use. Am J Trop Med Hyg. 2002;66(1):18-22

14. Pommier de Santi V, Girod R, Mura M, Dia A, Briolant S, Djossou F, et al. Epidemiological and entomological studies of a malaria outbreak among French armed forces deployed at illegal gold mining sites reveal new aspects of the disease's transmission in French Guiana. Malar J. 2016:15:35.

15. Klein TA, Lima JBP, Tada MS, Miller R. Comparative susceptibility of anopheline mosquitoes in Rondonia, Brazil to infection by Plasmodium vivax. Am J Trop Med Hyg. 1991;45(4):463-70.

16. Klein TA, Lima JBP, Tada MS. Comparative susceptibility of anopheline mosquitoes to Plasmodium falciparum in Rondonia, Brazil. Am J Trop Med Hyg. 1991;44(6):598-603.

17. Branquinho MS, Lagos CBT, Rocha RM, Natal D, Barata JS, Cochrane AH, et al. Anophelines in the state of Acre, Brazil, infected with Plasmodium falciparum, $P$. vivax, the variant $P$. vivax VK247 and P. malariae. Trans $R$ Soc Trop Med Hyg. 1993;87(4):391-4.

18. Póvoa MM, de Souza RTL, da Luz Lacerda RN, Rosa ES, Galiza D, de Souza $J R$, et al. The importance of Anopheles albitarsis E and An. darlingi in human malaria transmission in Boa Vista, state of Roraima, Brazil. Mem Inst Oswaldo Cruz. 2006;101(2):163-8.

19. Foley DH, Linton YM, Ruiz-Lopez JF, Conn JE, Sallum MAM, Póvoa MM, et al. Geographic distribution, evolution, and disease importance of species within the Neotropical Anopheles albitarsis Group (Diptera, Culicidae). J Vector Ecol. 2014:39(1):168-81.

20 Gil LHS, Rodrigues MdS, de Lima AA, Katsuragawa TH. Seasonal distribution of malaria vectors (Diptera: Culicidae) in rural localities of Porto Velho, Rondônia, Brazilian Amazon. Rev Inst Med Trop Sao Paulo. 2015:57(3):263-7.

21. da Silva-Vasconcelos A, Kató MY, Mourão EN, de Souza RT, da Lus Lacerda RN, Sibajev A, et al. Biting indices, host-seeking activity and natural infection rates of anopheline species in Boa Vista, Roraima, Brazil from 1996 to 1998. Mem Inst Oswaldo Cruz. 2002;97(2):151-61.

22 dos Santos RL, Forattini OP, Burattini MN. Anopheles albitarsis s.l. (Diptera: Culicidae) survivorship and density in a rice irrigation area of the State of São Paulo, Brazil. J Med Entomol. 2004;41(5):997-1000.

23. Póvoa MM, Wirtz RA, Lacerda RNL, Miles MA, Warhurst D. Malaria vectors in the municipality of Serra do Navio, State of Amapá, Amazon Region, Brazil. Mem Inst Oswaldo Cruz. 2001;96(2):179-84.

24. da Rocha JAM, de Oliveira SB, Póvoa MM, Moreira LA, Krettli AU, Malaria vectors in areas of Plasmodium falciparum epidemic transmission in the Amazon region, Brazil. Am J Trop Med Hyg. 2008;78(6):872-7.

25. Barros FSM, Honório NA, Arruda ME. Mosquito anthropophily: implications on malaria transmission in the Northern Brazilian Amazon. Neotrop Entomol. 2010:39(6):1039-43.

26 Laporta GZ, Linton YM, Wilkerson RC, Bergo ES, Nagaki SS, Sant'Ana DC, et al. Malaria vectors in South America: current and future scenarios. Parasit Vectors. 2015;8:426.

27 Motoki MT, Wilkerson RC, Sallum MAM. The Anopheles albitarsis complex with the recognition of Anopheles oryzalimnetes Wilkerson and Motoki, n. sp. and Anopheles janconnae Wilkerson and Sallum, n. sp. (Diptera: Culicidae). Mem Inst Oswaldo Cruz. 2009;104(6):823-50.

28. Rosa-Freitas MG. Anopheles (Nyssorhynchus) deaneorum: a new species in the albitarsis complex (Diptera: Culicidae). Mem Inst Oswaldo Cruz. 1989;84:535-43.

29. Rosa-Freitas MG, Deane LM. The neotype of Anopheles albitarsis (Diptera: culicidae). Mem Inst Oswaldo Cruz. 1989;84:289-302.

30. Linthicum KJ. A revision of the Argyritarsis section of the subgenus Nyssorhynchus of Anopheles (Diptera: Culicidae). Mosq Syst. 1988;20:98-271.

31. Brochero HHL, Li C, Wilkerson RC. A newly recognized species in the Anopheles (Nyssorhynchus) albitarsis complex (Diptera: Culicidae) from Puerto Carreno, Colombia. Am J Trop Med Hyg. 2007;76(6):1113-7.

32. Lehr MA, Kilpatrick CW, Wilkerson RC, Conn JE. Cryptic species in the Anopheles (Nyssorhynchus) albitarsis (Diptera: Culicidae) Complex: incongruence between random amplified polymorphic DNA-polymerase chain reaction identification and analysis of mitochondrial DNA COI gene sequences. Ann Entomol Soc Am. 2005:98(6):908-17. 
33. Wilkerson RC, Parsons TJ, Klein TA, Gaffigan TV, Bergo E, Consolim J. Diagnosis by random amplified polymorphic DNA polymerase chain reaction of four cryptic species related to Anopheles (Nyssorhynchus) albitarsis (Diptera: Culicidae) from Paraguay, Argentina, and Brazil. J Med Entomol. 1995;32(5):697-704.

34. Narang SK, Klein TA, Perera OP, Lima JB, Tang AT. Genetic evidence for the existence of cryptic species in the Anopheles albitarsis complex in Brazil: allozymes and mitochondrial DNA restriction fragment length polymorphisms. Biochem Genet. 1993;31(1):97-112.

35. Wilkerson RC, Foster PG, Li C, Sallum MAM. Molecular phylogeny of Neotropical Anopheles (Nyssorhynchus) albitarsis species complex (Diptera: Culicidae). Ann Entomol Soc Am. 2005;98(6):918-25.

36. Gutiérrez LA, Orrego LM, Gómez GF, López A, Luckhart S, Conn JE, et al. A New mtDNA COI gene lineage closely related to Anopheles janconnae of the Albitarsis Complex in the Caribbean region of Colombia. Mem Inst Oswaldo Cruz. 2010;105(8):1019-25.

37. Martinez-Villegas L, Assis-Geraldo J, Koerich LB, Collier TC, Lee Y, Main $\mathrm{BJ}$, et al. Characterization of the complete mitogenome of Anopheles aquasalis, and phylogenetic divergences among Anopheles from diverse geographic zones. PLoS ONE. 2019;14(9): e0219523.

38. Krzywinski J, Li C, Morris M, Conn JE, Lima JB, Povoa MM, et al. Analysis of the evolutionary forces shaping mitochondrial genomes of a Neotropical malaria vector complex. Mol Phylogenet Evol. 2011;58(3):469-77.

39. McKeon SN, Lehr MA, Wilkerson RC, Ruiz JF, Sallum MAM, Lima JBP, et al. Lineage divergence detected in the malaria vector Anopheles marajoara (Diptera: Culicidae) in Amazonian Brazil. Malar J. 2010;9:271.

40. Ladoukakis ED, Zouros E. Evolution and inheritance of animal mitochondrial DNA: rules and exceptions. J Biol Res. 2017;24:2.

41. Richards EJ, Brown JM, Barley AJ, Chong RA, Thomson RC. Variation across mitochondrial gene trees provides evidence for systematic error: How much gene tree variation is biological? Syst Biol. 2018;67(5):847-60.

42. González Obando R, Carrejo Gironza NS. Introducción al estudio taxónomico de Anopheles de Colombia: Claves y notas de distribución Colombia. Cali, Colombia: Universidad del Valle; 2009.

43. Gilbert MTP, Moore W, Melchior L, Worobey M. DNA extraction from dry museum beetles without conferring external morphological damage. PLOS ONE. 2007;2(3): e272

44. Andrews S. FastQC: a quality control tool for high throughput sequence data. 2010. http://www.bioinformatics.babraham.ac.uk/projects/fastqc.

45. Dierckxsens N, Mardulyn P, Smits G. NOVOPlasty: de novo assembly of organelle genomes from whole genome data. Nucleic Acids Res. 2017;45(4): e18

46. Cameron SL. How to sequence and annotate insect mitochondrial genomes for systematic and comparative genomics research. Syst Entomol. 2014;39(3):400-11.

47. Jühling F, Pütz J, Bernt M, Donath A, Middendorf M, Florentz C, et al. Improved systematic tRNA gene annotation allows new insights into the evolution of mitochondrial tRNA structures and into the mechanisms of mitochondrial genome rearrangements. Nucleic Acids Res. 2012;40(7):2833-45

48. Bernt M, Donath A, Jühling F, Externbrink F, Florentz C, Fritzsch G, et al MITOS: improved de novo metazoan mitochondrial genome annotation. Mol Phylogenet Evol. 2013;69(2):313-9.

49. Alikhan N-F, Petty NK, Ben Zakour NL, Beatson SA. BLAST ring image generator (BRIG): simple prokaryote genome comparisons. BMC Genom. 2011;12:402.

50. Gouy M, Guindon S, Gascuel O. SeaView version 4: a multiplatform graphical user interface for sequence alignment and phylogenetic tree building. Mol Biol Evol. 2010;27(2):221-4.

51. Abascal F, Zardoya R, Telford MJ. TranslatorX: multiple alignment of nucleotide sequences guided by amino acid translations. Nucleic Acids Res. 2010;38:W7-13.

52 Kumar S, Stecher G, Tamura K. MEGA7: Molecular Evolutionary Genetics Analysis version 7.0 for bigger datasets. Mol Biol Evol. 2016;33(7):1870-4.

53. Xia X, Xie Z, Salemi M, Chen L, Wang Y. An index of substitution saturation and its application. Mol Phylogenet Evol. 2003;26(1):1-7.

54. Xia X. DAMBE7: new and improved tools for data analysis in molecular biology and evolution. Mol Biol Evol. 2018;35(6):1550-2.

55. Woolley S, Johnson J, Smith MJ, Crandall KA, McClellan DA. TreeSAAP: selection on amino acid properties using phylogenetic trees. Bioinformatics. 2003:19(5):671-2.
56. McClellan DA, Ellison DD. Assessing and improving the accuracy of detecting protein adaptation with the TreeSAAP analytical software. Int J Bioinform Res Appl. 2010;6(2):120-33.

57. Maldonado E, Sunagar K, Almeida D, Vasconcelos V, Antunes A. IMPACT_S: integrated multiprogram platform to analyze and combine tests of selection. PLOS ONE. 2014;9(10): e96243.

58. Strimmer K, Von Haeseler A. Likelihood-mapping: a simple method to visualize phylogenetic content of a sequence alignment. Proc Natl Acad Sci USA. 1997;94(13):6815-9.

59. Nguyen L-T, Schmidt HA, von Haeseler A, Minh BQ. IQ-TREE: a fast and effective stochastic algorithm for estimating maximum-likelihood phylogenies. Mol Biol Evol. 2014;32(1):268-74.

60. Huson DH, Bryant D. Application of phylogenetic networks in evolutionary studies. Mol Biol Evol. 2006;23(2):254-67.

61. Kalyaanamoorthy S, Minh BQ, Wong TKF, Von Haeseler A, Jermiin LS. ModelFinder: fast model selection for accurate phylogenetic estimates. Nat Methods. 2017;14(6):587-9.

62. Grant T. Outgroup sampling in phylogenetics: severity of test and successive outgroup expansion. J Zool Syst Evol Res. 2019;57(4):748-63.

63. Cummins CA, Mclnerney JO. A method for inferring the rate of evolution of homologous characters that can potentially improve phylogenetic inference, resolve deep divergence and correct systematic biases. Syst Biol. 2011;60(6):833-44.

64. Ogilvie HA, Bouckaert RR, Drummond AJ. StarBEAST2 brings faster species tree inference and accurate estimates of substitution rates. Mol Biol Evol. 2017;34(8):2101-14.

65. Brower AV. Rapid morphological radiation and convergence among races of the butterfly Heliconius erato inferred from patterns of mitochondrial DNA evolution. Proc Natl Acad Sci. 1994;91(14):6491-5.

66. Yang Z, Rannala B. Unguided species delimitation using DNA sequence data from multiple loci. Mol Biol Evol. 2014;31(12):3125-35.

67. Flouri T, Jiao X, Rannala B, Yang Z. Species tree inference with BPP using genomic sequences and the multispecies coalescent. Mol Biol Evol. 2018;35(10):2585-93.

68. Leaché AD, Fujita MK. Bayesian species delimitation in West African forest geckos (Hemidactylus fasciatus). Proc R Soc B Biol Sci. 2010;277:3071-7.

69. Norris LC, Main BJ, Lee Y, Collier TC, Fofana A, Cornel AJ, et al. Adaptive introgression in an African malaria mosquito coincident with the increased usage of insecticide-treated bed nets. Proc Natl Acad Sci USA. 2015;112(3):815-20.

70 Hao YJ, Zou YL, Ding YR, Xu WY, Yan ZT, Li XD, et al. Complete mitochondrial genomes of Anopheles stephensi and An. dirus and comparative evolutionary mitochondriomics of 50 mosquitoes. Sci Rep. 2017;7(1):1-13.

71. Oliveira TMP, Foster PG, Bergo ES, Nagaki SS, Sanabani SS, Marinotti O, et al. Mitochondrial genomes of Anopheles (Kerteszia) (Diptera: Culicidae) from the Atlantic Forest. Brazil J Med Entomol. 2016:53(4):790-7.

72. Chen K, Wang Y, Li XY, Peng H, Ma YJ. Sequencing and analysis of the complete mitochondrial genome in Anopheles sinensis (Diptera: Culicidae). Infect Dis Poverty. 2017;6(1):149.

73. Buchon N, Broderick NA, Lemaitre B. Gut homeostasis in a microbial world: insights from Drosophila melanogaster. Nat Rev Microbiol. 2013;11:615-26.

74. Wallace DC. A mitochondrial paradigm of metabolic and degenerative diseases, ageing, and cancer: a dawn for evolutionary medicine. Annu Rev Genet. 2005;39:359-407.

75. Sanz A. Mitochondrial reactive oxygen species: do they extend or shorten animal lifespan? Biochim Biophys Acta Bioenerg. 2016;1857(8):1116-26.

76. Mehta MM, Weinberg SE, Chandel NS. Mitochondrial control of immunity: beyond ATP. Nat Rev Immunol. 2017;17(10):608-20.

77. Kausar S, Yang L, Abbas MN, Hu X, Zhao Y, Zhu Y, et al. Mitochondrial DNA: a key regulator of anti-microbial innate immunity. Genes. 2020;11(1):86.

78. Ferguson HM, Read AF. Why is the effect of malaria parasites on mosquito survival still unresolved? Trends Parasitol. 2002;18(6):256-61.

79. Edwards S, Beerli P. Perspective: gene divergence, population divergence, and the variance in coalescence time in phylogeographic studies. Evolution. 2000;54(6):1839-54.

80 Zavortink TJ, Poinar GO. Anopheles (Nyssorhynchus) dominicanus sp. N. (Diptera: Culicidae) from Dominican Amber. Ann Entomol Soc Am. 2000;93(6):1230-5. 
81. Statz G. Neue Dipteren (Nematocera) aus dem Oberoligocän von Rott. II. Teil. V. Familie Culicidae (Stechmücken). Palaeontogr Abt A. 1944;95:108-20.

82. Papadopoulou A, Anastasiou I, Vogler AP. Revisiting the insect mitochondrial molecular clock: the mid-Aegean trench calibration. Mol Biol Evol. 2010;27(7):1659-72.

83. Gibbard PL, Head MJ, Walker MJC, Alloway B, Beu AG, Coltorti M, et al. Formal ratification of the Quaternary System/Period and the Pleistocene Series/Epoch with a base at $2.58 \mathrm{Ma}$. J Quat Sci. 2010;25(2):96-102.

84. Roberts NJ, Barendregt RW, Clague JJ. Multiple tropical Andean glaciations during a period of late Pliocene warmth. Sci Rep. 2017;7:41878.

85. D'Apolito C, Absy ML, Latrubesse EM. The Hill of Six Lakes revisited: new data and re-evaluation of a key Pleistocene Amazon site. Quat Sci Rev. 2013;76:140-55.

86. Bloom DD, Lovejoy $N$. The biogeography of marine incursions in South America. In: Albert JS, Reis RE, editors. Historical biogeography of Neotropical freshwater fishes. Berkeley: University of California Press; 2011. p. 137-44.

87. Mirabello L, Conn JE. Population analysis using the nuclear white gene detects Pliocene/Pleistocene lineage divergence within Anopheles nuneztovari in South America. Med Vet Entomol. 2008;22(2):109-19.

88 Palacios C, García-R S, Parra JL, Cuervo AM, Stiles FG, McCormack JE, et al. Shallow genetic divergence and distinct phenotypic differences between two Andean hummingbirds: speciation with gene flow? Auk. 2019;136(4): ukz046.

89. Fouquet A, Noonan BP, Rodrigues MT, Pech N, Gilles A, Gemmell NJ. Multiple quaternary refugia in the eastern Guiana shield revealed by comparative phylogeography of 12 frog species. Syst Biol. 2012;61(3):461-89.

90. Prieto-Torres DA, Cuervo AM, Bonaccorso E. On geographic barriers and Pleistocene glaciations: tracing the diversification of the Russet-crowned Warbler (Myiothlypis coronata) along the Andes. PLoS ONE. 2018;13(3): e0191598.

91. Lavergne A, Ruiz-García M, Catzeflis F, Lacote S, Contamin H, MercereauPuijalon $\mathrm{O}$, et al. Phylogeny and phylogeography of squirrel monkeys (genus Saimiri) based on cytochrome b genetic analysis. Am J Primatol. 2010;72(3):242-53.

92. McKeon SN, Schlichting CD, Povoa MM, Conn JE. Ecological suitability and spatial distribution of five Anopheles species in Amazonian Brazil. Am J Trop Med Hyg. 2013;88(6):1079-86.

93. Sukumaran J, Knowles LL. Multispecies coalescent delimits structure, not species. Proc Natl Acad Sci USA. 2017;1 14(7):1607-12.

94. Foster PG, Bergo ES, Bourke BP, Oliveira TMP, Nagaki SS, Sant'Ana DC, et al. Phylogenetic analysis and DNA-based species confirmation in Anopheles (Nyssorhynchus). PLoS ONE. 2013;8(2): e54063.

95. Saraiva JF, Souto RNP, Scarpassa VM. Molecular taxonomy and evolutionary relationships in the Oswaldoi-Konderi complex (Anophelinae: Anopheles: Nyssorhynchus) from the Brazilian Amazon region. PLoS ONE. 2018;13(3): e0193591.

96 Sant'Ana DC, Sallum MAM. Anopheles (Nyssorhynchus) striatus, a new species of the Strodei Subgroup (Diptera, Culicidae). Rev Bras Entomol. 2017;61(2):136-45.

97. Bourke BP, Oliveira TP, Suesdek L, Bergo ES, Sallum MAM. A multi-locus approach to barcoding in the Anopheles strodei subgroup (Diptera: Culicidae). Parasit Vectors. 2013;6:111.

\section{Publisher's Note}

Springer Nature remains neutral with regard to jurisdictional claims in published maps and institutional affiliations.

Ready to submit your research? Choose BMC and benefit from:

- fast, convenient online submission

- thorough peer review by experienced researchers in your field

- rapid publication on acceptance

- support for research data, including large and complex data types

- gold Open Access which fosters wider collaboration and increased citations

- maximum visibility for your research: over $100 \mathrm{M}$ website views per year

At BMC, research is always in progress.

Learn more biomedcentral.com/submissions 